\title{
Ruminal metabolic parameters and milk fatty acid profile of cows grazing Marandu grass supplemented with roasted soybeans
}

\section{Parâmetros de metabolismo ruminal e perfil de ácidos graxos do leite de vacas Holandês $x$ Gir manejadas em pastagem de capim- Marandu suplementado com grão de soja tostado}

\author{
Mário Henrique França Mourthé ${ }^{\text {; }}$ Fernando César Ferraz Lopes ${ }^{2 *}$; Ronaldo Braga \\ Reis ${ }^{3}$; Marco Antônio Sundfeld da Gama ${ }^{4}$; Mirton José Frota Morenz \\ Bernardo Murta Salomão ${ }^{5}$
}

\begin{abstract}
The goal of this study was to evaluate the ruminal metabolic parameters and milk fatty acid composition of cows managed under continuous grazing on Marandu grass. Four rumen-cannulated Holstein x Gyr cows with an average milk yield of $21 \pm 2 \mathrm{~kg} \mathrm{day}^{-1}$ and $79 \pm 16$ days in milk were used in a $4 \mathrm{x} 4$ Latin Square design. Each cow received $6 \mathrm{~kg}$ day $^{-1}$ of a concentrate formulated with 0 (control), 1.3, 2.6 or $3.9 \mathrm{~kg}$ of roasted soybeans (as-fed basis), which were the experimental treatments. The inclusion of roasted soybeans promoted a linear reduction in the acetate concentration, with no effect on the $\mathrm{pH}$ and ruminal ammonia $\mathrm{N}$ concentration. There was no effect of the treatments on the ruminal degradability of the dry matter and neutral detergent fiber of Marandu grass or on the kinetic parameters of the fluids in the rumen. There were linear increases in the contents of fat and total solids in the milk and a linear decrease in the milk lactose content, but there was no effect of the treatments on the yield of these components or on milk yield. There were linear increases in milk fat stearic, elaidic, oleic, linoleic and $\alpha$-linolenic acidis contents, but there was no effect of the treatments on the milk fat contents of vaccenic and rumenic acids. Notably, supplementing Marandu grass with a concentrate containing up to $3.9 \mathrm{~kg}$ of roasted soybeans improved the nutritional quality of the milk fat due to increases in the milk fat contents of oleic and $\alpha$-linolenic acids, which are considered beneficial to human health, and reductions in the levels of lauric, myristic and palmitic, which are considered hypercholesterolemic fatty acids.
\end{abstract}

Key words: Conjugated linoleic acid. Rumenic acid. Ruminal metabolite. Urochloa brizantha.

\section{Resumo}

Objetivou-se neste estudo avaliar parâmetros de metabolismo no rúmen e o perfil de ácidos graxos do leite de vacas manejadas sob pastejo contínuo em capim-Marandu. Foram utilizadas quatro vacas

\footnotetext{
1 Prof. Adjunto, Instituto de Ciências Agrárias, Universidade Federal de Minas Gerais, UFMG, Montes Claros, MG, Brasil. E-mail: mariohfm@ica.ufmg.br

2 Analista, Empresa Brasileira de Pesquisa Agropecuária, EMBRAPA Gado de Leite, Juiz de Fora, MG, Brasil. E-mail: fernando. lopes@embrapa.br

3 Prof. Titular, Departamento de Zootecnia, Escola de Veterinária, UFMG, Belo Horizonte, MG, Brasil. E-mail: rbreis@vet.ufmg. com.br

4 Pesquisadores, EMBRAPA Gado de Leite, Juiz de Fora, MG, Brasil. E-mail: marco.gama@embrapa.br; mirton.morenz@ embrapa.br

5 M.e em Zootecnia, BMS Consultoria, Águas Formosas, MG, Brasil. E-mail: murtabernardo@gmail.com

* Autor para correspondência
} 
mestiças Holandês x Gir com $79 \pm 16$ dias de lactação, produzindo $21 \pm 2 \mathrm{~kg} \mathrm{dia}^{-1}$ de leite, canuladas no rúmen e alocadas em delineamento Quadrado Latino 4 x 4 . Cada vaca recebeu $6 \mathrm{~kg} \mathrm{dia}^{-1}$ de concentrado formulado com 0 (Controle); 1,3; 2,6 ou 3,9 $\mathrm{kg}$ de grão de soja tostado (base matéria natural), que consistiram nos tratamentos experimentais. A inclusão de grão de soja tostado promoveu redução linear na concentração de acetato, sem efeito sobre o $\mathrm{pH}$ e a concentração de $\mathrm{N}$ amoniacal no rúmen. Não houve efeito dos tratamentos sobre a degradabilidade ruminal da matéria seca e da fibra em detergente neutro do pasto, nem sobre os parâmetros da cinética de fluidos no rúmen. Houve incremento linear nos teores de gordura e de sólidos totais e redução linear no teor de lactose do leite, mas não houve efeito dos tratamentos sobre as produções destes componentes nem sobre a produção de leite. Houve incremento linear nos teores dos ácidos graxos esteárico, elaídico, oleico, linoleico e $\alpha$-linolênico no leite, mas não houve efeito dos tratamentos sobre os teores no leite dos ácidos vacênico e rumênico. A suplementação do pasto de capim-Marandu com concentrado contendo até 3,9 kg de grão de soja tostado melhorou a qualidade nutricional da gordura do leite, com aumento nos teores dos ácidos oleico e $\alpha$-linolênico, benéficos à saúde humana, e redução dos teores dos ácidos graxos hipercolesterolêmicos láurico, mirístico e palmítico.

Palavras-chave: Ácido linoleico conjugado. Ácido rumênico. Metabólito ruminal. Urochloa brizantha.

\section{Introduction}

The main isomer of CLA (conjugated linoleic acid) in ruminant milk fat is rumenic acid (cis9, trans-11 CLA), which has anticarcinogenic, antidiabetogenic (type 2 diabetes), antiatherogenic and immunomodulatory properties (YANG et al., 2015).

Studies show that tropical grasses managed under grazing have high levels of polyunsaturated fatty acids (FA), mainly $\omega-3 \alpha$-linolenic acid (cis9, cis-12, cis-15 C18:3) and, to a lesser extent, $\omega-6$ linoleic acid (cis-9, cis-12 C18:2), which are the main substrates for the formation of vaccenic acid (trans-11 C18:1) in the rumen (LOPES et al., 2015; KLIEM; SHINGFIELD, 2016). However, oilseeds, such as soybeans, are among the main sources of linoleic acid in ruminant diets in Brazil (LOPES et al., 2011).

In the mammary gland, trans-11 C18:1 is the precursor for the synthesis of $70-95 \%$ of all rumenic acid secreted in bovine milk (KLIEM; SHINGFIELD, 2016). In addition, in human tissues, approximately $19 \%$ of the consumed trans-11 C18:1 is converted to rumenic acid (TURPEINEN et al., 2002). The remainder of the bovine milk rumenic acid is derived from the isomerization of linoleic acid in the rumen, followed by ruminal escape and intestinal absorption of the rumenic acid, its uptake from the blood by the mammary gland and its esterification into the triglycerides in milk fat.

In addition to the rumenic and trans-11 C18:1 FA, the fat in ruminant milk contains other FAs whose consumption benefits human health (FAO, 2010), such as oleic (cis-9 C18:1), linoleic and $\alpha$-linolenic acids.

Thus, several studies focusing on nutritional strategies, such as lipid supplementation of the pasture grasses, have been carried out in Brazil (LOPES et al., 2015) and throughout the world (KLIEM; SHINGFIELD, 2016), aiming at obtaining dairy products enriched with the FAs that are considered to be beneficial to health.

Roasted soybeans (RS) is a concentrate feed with relevant nutritional characteristics for inclusion in diets for lactating cows because it is an important source of energy and of rumen undegradable protein (TICE et al., 1993) and has a high content of linoleic acid (e.g., 53.2\% of total FAs; MOURTHÉ et al., 2015).

In companion studies carried out concomitantly with the present study but with the main objective of evaluating the productive performance of the cows, Mourthé et al. $(2012,2015)$ observed an increase 
in the milk fat content and yield. In addition, there was an improvement in the milk FA profile that was promoted by decreases in the milk fat contents of lauric (C12:0), myristic (C14:0) and palmitic (C16:0) acids, which are considered hypercholesterolemic (FAO, 2010), and by increases in the milk fat contents of oleic and $\alpha$-linolenic acids. In addition, high milk fat contents of trans-11 C18:1 (2.19-2.57 g 100

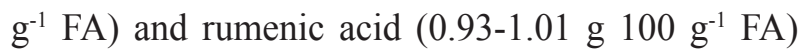
were obtained (MOURTHÉ et al., 2015), illustrating the potential of milk production systems based on tropical grass pasture supplemented with RS.

Thus, the goal of the present study was to evaluate the ruminal metabolism of the consumed diets and to associate them with the results of the fatty acid composition in the milk fat of Holstein x Gyr dairy cows grazing on Marandu grass supplemented with increasing amounts of roasted soybeans in the concentrate.

\section{Materials and Methods}

The study was carried out from February to April 2009, at the Experimental Field José Henrique Bruschi, from Embrapa Dairy Cattle (Coronel Pacheco, MG, Brazil), and the meteorological data observed in the experimental period are presented in Table 1.

Table 1. Meteorological data observed during the experimental period (Coronel Pacheco, MG, Brazil).

\begin{tabular}{lccccc}
\hline \multirow{2}{*}{ Month/2009 } & $\begin{array}{c}\text { Total precipitation } \\
(\mathrm{mm})\end{array}$ & \multicolumn{3}{c}{ Temperature $\left({ }^{\circ} \mathrm{C}\right)$} & Relative humidity \\
\cline { 3 - 5 } & 267.9 & Maximum & Average & Minimum & 79.8 \\
\hline January & 149.3 & 31.7 & 24.5 & 20.3 & 78.4 \\
February & 167.1 & 31.2 & 24.9 & 20.5 & 80.0 \\
March & 11.4 & 28.9 & 24.7 & 20.5 & 79.4 \\
April & & 22.0 & 17.6 & \\
\hline
\end{tabular}

Source: INMET - Instituto Nacional de Meteorologia <http://www.inmet.gov.br/portal/>.

The experimental protocol was approved by the Animal Experimentation Ethics Committee of the Federal University of Minas Gerais, Belo Horizonte, MG, Brazil (CETEA Protocol \#196/08). Four rumen-fistulated multiparous Holstein x Gyr crossbred cows in the initial third of the lactation ( $79 \pm 16$ days), with $567 \pm 39 \mathrm{~kg}$ body weight and producing on average $21 \pm 2 \mathrm{~kg}$ day $^{-1}$ of milk, were used. A 4 x 4 Latin square (LS) experimental design was adopted. Each LS period comprised 16 days with 10 days for adaptation to the diets and 6 days for the sampling and data recording.

Throughout the experimental period, the four cows in the present experiment and the 16 cows from the companion work of Mourthé et al. (2012) were managed together under continuous stocking on 9.5 ha of Urochloa brizantha cv. Marandu pasture. The average stocking rate in this pasture was 2.4 animal units ha ${ }^{-1}$ throughout the experiment. The main target of the management of this pasture was to ensure that the forage allowance was not limiting for the 20 cows. To obtain this objective and to allow the estimation of the mass of forage in the pasture during the experimental period, five pasture samplings were performed: four on the first day of each LS period, and one on the last day of the experiment. The pasture sampling procedures were presented by Mourthé et al. (2012). During the experimental period, the average DM forage allowance was $22.6 \mathrm{~kg} 100 \mathrm{~kg}^{-1}$ live weight, corresponding to $119 \mathrm{~kg} \mathrm{cow}^{-1}$ day $^{-1}$ of pasture DM. This result shows that the pasture management target was reached; therefore, the forage allowance was not limiting for the selective grazing of the 
cows, as indicated by the good nutritional quality of the forage selected in the pasture (Table 2).

The experimental treatments consisted of pasture supplementation with concentrates formulated with 0 (control), $1.2,2.4$ or $3.6 \mathrm{~kg}$ of $\mathrm{DM}$ from roasted soybeans - RS $(0,1.3,2.6$ or $3.9 \mathrm{~kg}$ of $\mathrm{RS}$, respectively, as-fed basis) (Table 3). The RS partially replaced the energy from ground corn and citrus pulp, as well as the protein from soybean meal. The daily amount of concentrate $\left(6 \mathrm{~kg} \mathrm{cow}^{-1}\right.$, as-fed basis) was divided into two equal parts and supplied after the morning (05h00) and the afternoon (14h00) milking in electronic troughs (American Calan Inc., Northewood, NW, USA) installed in a free-stall barn. The RS were previously ground in a mill with a $10 \mathrm{~mm}$ mesh sieve before being mixed with the experimental concentrates, which were prepared weekly, to avoid lipid peroxidation. Toasting of the soybeans was performed under temperatures ranging from $145-149^{\circ} \mathrm{C}$ for $30-45 \mathrm{sec}$, with 35 min of steeping (storage in a thermal container after processing, so that the heat penetrated deeper into the grain).

Table 2. Chemical composition and fatty acid profile of the pasture (extrusa) and roasted soybeans.

\begin{tabular}{lcc}
\hline Item & Extrusa $^{1}$ & Roasted soybeans \\
\hline Chemical composition & & 92.6 \\
\hline Dry matter - DM (\%) & 12.5 & 38.6 \\
Crude protein (\% DM) & 10.8 & 19.1 \\
Neutral detergent fiber (\% DM) & 69.7 & 22.3 \\
Ether extract (\% DM) & 1.2 & Not determined $^{2}$ \\
In vitro DM digestibility (\%) & 66.6 & Roasted soybeans $^{2}$ \\
\hline Fatty acid (g 100 g-1 total fatty acids) & Extrusa $^{2}$ & 11.4 \\
\hline C16:0 & 23.5 & 2.4 \\
C18:0 & 3.0 & 53.2 \\
cis-9 C18:1 & 4.6 & 6.8 \\
cis-9, cis-12 C18:2 & 19.7 & \\
cis-9, cis-12, cis-15 C18:3 & 42.4 & \\
\hline
\end{tabular}

1Source: Mourthé et al. (2012).

${ }^{2}$ Source: Mourthé et al. (2015).

Table 3. Ingredients and chemical composition of the experimental concentrates containing increasing amounts of roasted soybeans $(\mathrm{RS})$.

\begin{tabular}{|c|c|c|c|c|}
\hline \multirow{2}{*}{ Item } & \multicolumn{4}{|c|}{ RS in the concentrate $(\mathrm{kg})$} \\
\hline & 0.0 & 1.3 & 2.6 & 3.9 \\
\hline \multicolumn{5}{|c|}{ Ingredient (kg of as-fed) } \\
\hline $\mathrm{RS}^{1}$ & 0.0 & 1.3 & 2.6 & 3.9 \\
\hline Soybean meal & 2.7 & 1.9 & 1.2 & 0.5 \\
\hline Ground corn & 1.6 & 1.3 & 1.0 & 0.7 \\
\hline Citric pulp & 1.5 & 1.3 & 1.0 & 0.7 \\
\hline Mineral/vitamin supplement ${ }^{2}$ & 0.2 & 0.2 & 0.2 & 0.2 \\
\hline
\end{tabular}


continuation

\begin{tabular}{lcccc}
\hline \multicolumn{1}{c}{ Chemical composition (\% dry matter) } & & & & \\
\hline Crude protein (CP) & 28.5 & 30.4 & 30.9 & 32.9 \\
Neutral detergent fiber (NDF) & 16.8 & 17.4 & 21.0 & 20.1 \\
Ether extract (EE) & 2.6 & 8.7 & 11.3 & 16.5 \\
Nonfibrous carbohydrates & 43.1 & 35.4 & 28.5 & 22.9 \\
Mineral matter & 9.0 & 8.1 & 8.3 & 7.6 \\
In vitro dry matter digestibility (\%) & 95.4 & 94.1 & 90.7 & 84.6 \\
Net energy for lactation - $\mathrm{NE}_{\mathrm{L}}\left(\mathrm{Mcal} \mathrm{kg}^{-1}\right)^{4}$ & 1.77 & 1.82 & 1.87 & 1.91 \\
\hline \multicolumn{1}{c}{ Fatty acid (\% dry matter) } & & & \\
\hline C16:0 $\quad 0.557$ & 1.215 & 1.593 & 2.379 \\
C18:0 cis-9 C18:1 & 0.099 & 0.324 & 0.445 & 0.692 \\
cis-9, cis-12 C18:2 & 0.692 & 2.047 & 2.779 & 4.389 \\
cis-9, cis-12, cis-15 C18:3 & 1.230 & 4.799 & 6.686 & 10.702 \\
\hline
\end{tabular}

${ }^{1} \mathrm{RS}(\%$ dry matter $)=38.6 \% \mathrm{CP} ; 22.3 \% \mathrm{EE} ; 19.1 \% \mathrm{NDF} ; 3.02 \% \mathrm{C} 16: 0 ; 0.90 \% \mathrm{C} 18: 0 ; 5.87 \%$ cis-9 C18:1; 14.11\% cis-9, cis-12 C18:2; $1.79 \%$ cis-9, cis-12, cis-15 C18:3.

${ }^{2}$ Top Milk Núcleo ${ }^{\circledR}$ (Matsuda, Álvares Machado, SP, Brazil): contained per kg: 255 g Ca, 76 g P, 20 g S, 30 g Mg, 60 mg Co, 850 $\mathrm{mg} \mathrm{Cu}, 65 \mathrm{mg} \mathrm{I}, 2,000 \mathrm{mg} \mathrm{Mn}, 20 \mathrm{mg} \mathrm{Se}, 6,000 \mathrm{mg} \mathrm{Zn,} \mathrm{1,000} \mathrm{mg} \mathrm{Fe,} 760 \mathrm{mg} \mathrm{F}, 220,000 \mathrm{IU}$ of vitamin A, $500 \mathrm{IU}$ of vitamin E.

${ }^{3}$ Values extracted from Mourthé et al. (2012).

${ }^{4}$ Estimated from the values calculated by Valadares Filho et al. (2010) and by the equation $\mathrm{NE}_{\mathrm{L}}=0.0245 * \mathrm{TDN}-0.12(\mathrm{NRC}, 2001)$.

Samples of the experimental concentrates and RS were collected in each LS period and frozen for chemical analysis. On the first day of each LS period, forage samples were collected from the pasture using a lactating cow with an esophageal fistula that was adapted to grazing in the experimental area. The extrusa (ingested grass + saliva) collection lasted approximately $40 \mathrm{~min}$ and was performed soon after the morning milking. The extrusa sample that accumulated in the collection bag was fractionated in three parts, which were packed in plastic bags and frozen.

The first fraction of the extrusa samples, as well as the experimental concentrates and RS samples collected in each LS period, were lyophilized and milled to analyze the FA composition (Tables 2 and 3). These samples were subjected to digestion according to method 996.06 (AOAC, 2005), and methylation was performed according to Hartman and Lago (1973). The FA methyl esters (FAME) were analyzed using gas chromatography (Agilent 6890N, Agilent Technologies, Santa Clara,
CA, USA) with a fused silica capillary column of cyanopropyl siloxane ( $60 \mathrm{~m}$ x $0.32 \mathrm{~mm}$ x $0.25 \mu \mathrm{m})$ and a flame ionization detector (FID).

The second fraction of the extrusa samples was thawed, dried in a forced-air circulation oven $\left(55^{\circ} \mathrm{C}, 72 \mathrm{~h}\right)$, milled $(1 \mathrm{~mm})$ and, together with the experimental concentrates and RS samples, analyzed for DM (at $105^{\circ} \mathrm{C}$ ), crude protein (CP), ether extract (EE) and neutral detergent fiber (NDF), according to the methods described by Detmann et al. (2012). For the extrusa and concentrate samples, the in vitro DM digestibility (IVDMD) was also estimated, as described by Mourthé et al. (2012) (Tables 2 and 3).

The third fraction of the extrusa samples was thawed, dried, milled ( $5 \mathrm{~mm}$ ) in a Willey knife mill and used for estimating the ruminal degradation parameters of DM and NDF (NOCEK, 1988). For the analysis of ruminal degradation, the dried extrusa samples were packed in nylon bags $(10 \mathrm{x}$ $20 \mathrm{~cm}$; $50 \mu$ porosity; 10-20 $\mathrm{mg}$ of sample per $\mathrm{cm}^{2}$ ), with the zero time bags being washed and frozen, while the other bags were incubated in the rumen 
of each cow on the morning of the $11^{\text {th }}$ day of each LS period, removed 2, 6, 12, 24, 48 and 96 hours after insertion, and frozen. Subsequently, they were washed, dried and weighed, and the residues were analyzed (DETMANN et al., 2012). The ruminal degradability parameters were estimated by adjusting the degradation data as a function of time to the nonlinear model described by Tomich and Sampaio (2004) using the NLIN procedure of SAS version 9.0. Curves were generated for each cow in each LS period. The DM and NDF effective degradability were calculated according to Ørskov and McDonald (1979) using the particulate ruminal passage rate of $5 \%$ hour $^{-1}$.

The ruminal parameters were evaluated on the $13^{\text {th }}$ and $14^{\text {th }}$ days of each LS period; samples of rumen fluid were collected immediately before (time zero) and at 2, 4, 6, 8, 10, 12 and 24 hours after the concentrate was supplied in the morning. Then, the $\mathrm{pH}$ was measured. Two $10-\mathrm{mL}$ aliquots were added to flasks with $0.4 \mathrm{~mL}$ of $\mathrm{H}_{2} \mathrm{SO}_{4} 50 \% \mathrm{v} / \mathrm{v}$ (subsample 1) or $2 \mathrm{~mL}$ of metaphosphoric acid $25 \%$ $\mathrm{v} / \mathrm{v}$ (subsample 2) and frozen for further analysis of the ammonia $\mathrm{N}$ concentration (subsample 1) according to the INCT-CA N-007/1 method (DETMANN et al., 2012) and for the analysis of the molar concentration $(\mathrm{m} M)$ of the volatile fatty acids (VFA) acetate, propionate and butyrate (subsample 2). The VFA concentrations were analyzed using gas chromatography (Agilent 6890N, Agilent Technologies) with an FID and Nukol capillary column (30 m x $22 \mathrm{~mm} \times 0.25 \mu \mathrm{m})$ connected to free FA (SUPELCO, Bellefonte, PA, USA).

For the analysis of the kinetics of the fluids in the rumen performed on the $13^{\text {th }}$ and $14^{\text {th }}$ days of each LS period, $5 \mathrm{~g}$ of Co-EDTA (11.2\% Co, DM basis) obtained according to the procedure in Udén et al. (1980) were diluted in $200 \mathrm{~mL}$ of distilled water and intraruminally administered to the cows before the concentrate was supplied in the morning. At the same time that the samples for the ruminal fermentation parameters analyses were taken, $5 \mathrm{~mL}$ of ruminal fluid was further collected, transferred to tubes and frozen for further Co analysis by atomic absorption spectrophotometry (UDÉN et al., 1980). The kinetic parameters of the fluids in the rumen were estimated by adjusting the Co concentrations in the rumen fluid as a function of time with the unicompartmental exponential model reported by Valadares Filho and Pina (2011), using the NLIN procedure of SAS.

The pasture DM intake of the cows was estimated from the $11^{\text {th }}$ to the $15^{\text {th }}$ day of each LS period using the external marker chromium oxide $\left(\mathrm{Cr}_{2} \mathrm{O}_{3}\right)$ and the IVDMD of the grasses from the pasture and concentrate. The procedures for administering the marker and sampling, processing and analyzing the $\mathrm{Cr}$ content in the feces, in addition to the formulas to estimate pasture DM intake, were performed as described by Mourthé et al. (2012).

Milk yields were recorded from the $11^{\text {th }}$ to the $15^{\text {th }}$ day of each LS period. Aliquots of milk from each milking ( $2 / 3$ at morning milking $+1 / 3$ at afternoon milking) were collected to compose individual samples $(30 \mathrm{~mL})$, which were stored in bottles with a bronopol preservative for the analysis of protein, fat, lactose and total solids, which were performed by medium infrared spectrometry (Bentley 2300; Bentley Instruments, Inc., Chaska, MN, USA), and for the analysis of milk urea nitrogen (MUN).

On the $15^{\text {th }}$ day of each LS period, individual samples of milk were collected in bottles without a preservative and frozen to determine the FA profile. Briefly, the milk lipids were extracted using ammonium hydroxide, ethanol, diethyl ether, and hexane according to reference method 989.05 (AOAC, 2006). After solvent evaporation under oxygen-free nitrogen, the extracted milk lipids were dissolved in hexane and methyl acetate and transesterified to FAME using freshly prepared methanolic sodium methoxide (CHRISTIE, 1982). The mixture was neutralized with oxalic acid, and calcium chloride was added to remove the methanol residues. The FAME in a $1.0 \mu \mathrm{L}$ sample at a split ratio of 1:50 were separated and quantified using 
a gas chromatograph (model 6890N, Agilent Technologies) fitted with a FID and equipped with a fused-silica capillary column $(100 \mathrm{~m} \times 0.25 \mathrm{~mm}$ x $0.2 \mu m$ film thickness; CP-SIL 88, Varian Inc., Mississauga, ON, USA). The operating conditions included injector and detector temperatures both at $250^{\circ} \mathrm{C}$ and $\mathrm{H}_{2}$ as the carrier gas $\left(1 \mathrm{~mL} \mathrm{~min}^{-1}\right)$, and for the FID (35 $\left.\mathrm{mL} \mathrm{min}^{-1}\right), \mathrm{N}_{2}$ was the makeup gas (30 $\left.\mathrm{mL} \mathrm{min}^{-1}\right)$ along with purified air $\left(286 \mathrm{~mL} \mathrm{~min}{ }^{-1}\right)$. The initial temperature was $45^{\circ} \mathrm{C}$ and held for $4 \mathrm{~min}$, increased by $13^{\circ} \mathrm{C} \mathrm{min}^{-1}$ to $175^{\circ} \mathrm{C}$ and held for 27 min, and increased by $4^{\circ} \mathrm{C} \mathrm{min}^{-1}$ to $215^{\circ} \mathrm{C}$ and held for $35 \mathrm{~min}$ (CRUZ-HERNANDEZ et al., 2007). The FAME were identified by comparison of their retention times with 4 reference FAME standards (Supelco $^{\circledR} 37$ Component FAME Mix \#47885-U and Linoleic Acid Methyl Ester Mix \#47791 from Sigma-Aldrich, St. Louis, MO, USA; Luta-CLA ${ }^{\circledR}$ 60 from BASF S/A, São Paulo, Brazil; and GLC463 from Nu-Chek Prep, Inc., Elysian, MN, USA) and according to their order of elution reported under the same analytical conditions (CRUZHERNANDEZ et al., 2007; KRAMER et al., 2008). The milk FA composition was expressed as a weighted percentage of total FA (g $100 \mathrm{~g}^{-1}$ total FA) using the theoretical relative response factors described by Wolff et al. (1995).

The nutritional quality of milk fat was evaluated by the atherogenicity (AI) and thrombogenicity (TI) indices, and by the ratios between omega 6 and omega 3 FAs ( $\omega-6 / \omega-3$ FA ratio) and between hypoand hypercholesterolemic FAs (h/H FA ratio). These indices were calculated according to the following equations: $\mathrm{AI}=\left[\mathrm{C} 12: 0+\left(4^{*} \mathrm{C} 14: 0\right)+\mathrm{C} 16: 0\right] /($ cis -9 $\mathrm{C} 18: 1+\Sigma \omega-6$ cis $\mathrm{FA}+\Sigma \omega-3$ cis $\mathrm{FA}) ; \mathrm{TI}=(\mathrm{C} 14: 0$ $+\mathrm{C} 16: 0+\mathrm{C} 18: 0) /\left[\left(0.5^{*}\right.\right.$ cis $\left.-9 \mathrm{C} 18: 1\right)+\left(0.5^{*} \Sigma \omega-6\right.$ cis $\mathrm{FA})+\left(3^{*} \Sigma \omega-3\right.$ cis $\left.\mathrm{FA}\right)+\left(\sum \omega-3\right.$ cis $\mathrm{FA} / \Sigma \omega-6$ cis FA)]; $\omega-6: \omega-3$ FA ratio $=\Sigma \omega-6$ cis $\mathrm{FA} / \Sigma \omega-3$ cis $\mathrm{FA}$; and $\mathrm{h} / \mathrm{H} \mathrm{FA}$ ratio $=($ cis $-9 \mathrm{C} 18: 1+\Sigma \omega-3$ cis $\mathrm{FA}) /(\mathrm{C} 12: 0+\mathrm{C} 14: 0+\mathrm{C} 16: 0)$, where $\Sigma \omega-3$ cis FA $=c i s-9, c i s-12, c i s-15 \mathrm{C} 18: 3$, and $\Sigma \omega-6$ cis $\mathrm{FA}=$ cis-9, cis-12 C18:2 + cis-6, cis-9, cis-12 $\gamma-\mathrm{C} 18: 3+$ cis-11, cis-14 C20:2 + cis-8, cis-11, cis-14 C20:3 + cis-5, cis-8, cis-11, cis-14 C20:4.

The index of stearoyl-CoA delta-9 desaturase (SCD) activity was calculated for four pairs of FAs that represent products and substrates for SCD: cis $^{-9}$ 14:1/C14:0, cis-9 16:1/C16:0, cis-9 18:1/C18:0, and cis-9, trans-11 CLA/trans-11 C18:1. The desaturase indices were obtained as described by Kelsey et al. (2003) as follows: (product of SCD)/(product of SCD + substrate of SCD).

On the $16^{\text {th }}$ day of each LS period, after the morning milking, blood samples were collected by puncture of the coccygeal vein using vacuum tubes (Vacutainer, Becton-Dickinson, Rutherford, NJ, USA) without anticoagulant or containing K-EDTA, respectively, for analysis of plasmatic glucose and nonesterified FA (NEFA) concentrations. These tubes were immediately centrifuged $(3,200 \mathrm{x} \mathrm{g}$; $15 \mathrm{~min}$ ) for plasma extraction, which in turn was transferred and frozen in microtubes $(2 \mathrm{~mL})$. The glucose concentration analysis was performed by an enzymatic-colorimetric method in a Biochemistry Analyzer 2700 (YSI, Inc., Yellow Springs, OH, USA), while the plasma NEFA content was determined using the commercial kit NEFAC (Wako Pure Chemicals Industries Ltd., Osaka, Japan).

The results were analyzed using SAS version 9.0. The ruminal fermentation parameters were analyzed as repeated measures in time and were considered to be fixed effects: treatment ( $\mathrm{kg}$ of $\mathrm{RS}$ in the concentrate), sampling time and interaction between these factors, and random effects: cow, LS period and the interaction cow*LS period*treatment. Ten matrices of covariance were evaluated, based on the Akaike information criterion. The other variables were analyzed considering treatment as a fixed effect and cow and LS period as random effects. The linear and quadratic effects of the treatments were analyzed using orthogonal contrasts. Regression equations between specific variables were adjusted by the REG procedure and Pearson correlations obtained by the CORR procedure of SAS. Significant differences were declared at $\mathrm{P} \leq 0.05$. 


\section{Results}

There was no effect of the inclusion of RS on the intake of DM, NDF and linoleic and $\alpha$-linolenic acids from the pasture or on the total DM, NDF and $\mathrm{CP}$ intakes. RS supplementation promoted a linear decrease $(P=0.01)$ in nonfibrous carbohydrate $(\mathrm{NFC})$ intake and a linear increase $(\mathrm{P}<0.0001)$ in the total intake of EE and of palmitic, stearic, oleic, linoleic and $\alpha$-linolenic acids (Table 4 ). There was no effect of the treatments on the proportions of roughage and concentrate calculated in the final diets (Table 4), which ranged from 71:29 to 73:27 (DM basis).

The inclusion of RS did not alter the ruminal degradability parameters for DM and NDF of the pasture or the kinetic parameters of the fluids in the rumen (Table 5).

Table 4. Nutrient and fatty acid intake by Holstein x Gyr cows grazing on Marandu grass supplemented with concentrates containing increasing amounts of roasted soybeans (RS).

\begin{tabular}{|c|c|c|c|c|c|c|c|}
\hline \multirow{2}{*}{ Item $^{1}$} & \multicolumn{4}{|c|}{$\mathrm{RS}$ in the concentrate $(\mathrm{kg})$} & \multirow{2}{*}{$\begin{array}{l}\text { Standard error } \\
\text { of the mean }\end{array}$} & \multicolumn{2}{|c|}{ P-value } \\
\hline & 0.0 & 1.3 & 2.6 & 3.9 & & Linear & Quadratic \\
\hline \multicolumn{8}{|l|}{ Nutrient intake $\left(\mathrm{kg}\right.$ day $\left.^{-1}\right)$} \\
\hline Pasture DM & 13.7 & 14.4 & 14.1 & 12.7 & 1.3833 & 0.5609 & 0.4351 \\
\hline Pasture NDF & 9.56 & 10.05 & 9.81 & 8.83 & 0.9636 & 0.5620 & 0.4356 \\
\hline Total DM (pasture + concentrate) & 18.8 & 19.6 & 19.2 & 17.8 & 1.3817 & 0.5883 & 0.4346 \\
\hline Total NDF & 10.4 & 10.9 & 10.9 & 9.9 & 0.9636 & 0.6828 & 0.4124 \\
\hline Total CP & 2.92 & 3.12 & 3.10 & 3.07 & 0.1484 & 0.5289 & 0.4362 \\
\hline Total EE & 0.29 & 0.62 & 0.74 & 1.01 & 0.0160 & $<0.0001$ & 0.0912 \\
\hline Total NFC & 3.15 & 3.14 & 2.78 & 2.57 & 0.1398 & 0.0143 & 0.4878 \\
\hline \multicolumn{8}{|l|}{ Roughage:concentrate in the final diet } \\
\hline Grass ratio & 0.72 & 0.73 & 0.73 & 0.71 & 0.0205 & 0.6038 & 0.2710 \\
\hline Concentrate ratio & 0.28 & 0.27 & 0.27 & 0.29 & 0.0205 & 0.5999 & 0.2733 \\
\hline \multicolumn{8}{|c|}{ Nutrient intake (g $100 \mathrm{~g}^{-1}$ live weight) } \\
\hline Pasture NDF & 1.68 & 1.73 & 1.75 & 1.57 & 0.1819 & 0.6674 & 0.4881 \\
\hline Total NDF & 1.83 & 1.89 & 1.94 & 1.76 & 0.1832 & 0.8190 & 0.4666 \\
\hline Pasture DM & 2.41 & 2.49 & 2.51 & 2.26 & 0.2613 & 0.6663 & 0.4877 \\
\hline Total DM & 3.30 & 3.38 & 3.42 & 3.18 & 0.2693 & 0.7554 & 0.5064 \\
\hline \multicolumn{8}{|l|}{ Fatty acid intake $\left(\mathrm{g} \mathrm{day}^{-1}\right)$} \\
\hline Total palmitic acid & 57.4 & 93.3 & 111.1 & 149.9 & 2.9229 & $<0.0001$ & 0.6044 \\
\hline Total stearic acid & 8.8 & 20.7 & 26.6 & 39.2 & 0.3868 & $<0.0001$ & 0.3031 \\
\hline Total oleic acid & 40.8 & 111.4 & 147.4 & 231.9 & 0.9641 & $<0.0001$ & $<0.0001$ \\
\hline Linoleic acid from concentrate & 62.3 & 246.9 & 340.4 & 552.7 & 2.0761 & $<0.0001$ & $<0.0001$ \\
\hline Linoleic acid from pasture $^{2}$ & 24.7 & 26.0 & 25.4 & 22.8 & 2.4913 & 0.5611 & 0.4362 \\
\hline Total acid linoleic & 87.0 & 272.9 & 365.7 & 575.5 & 2.9875 & $<0.0001$ & 0.0032 \\
\hline$\alpha$-linolenic acid from concentrate & 5.3 & 30.3 & 43.0 & 70.0 & 0.2618 & $<0.0001$ & 0.0015 \\
\hline$\alpha$-linolenic acid from pasture ${ }^{2}$ & 53.1 & 55.8 & 54.5 & 49.0 & 5.3538 & 0.5616 & 0.4354 \\
\hline Total $\alpha$-linolenic acid & 58.4 & 86.1 & 97.5 & 119.0 & 5.3173 & $<0.0001$ & 0.5452 \\
\hline
\end{tabular}

${ }^{1} \mathrm{DM}=$ dry matter, $\mathrm{NDF}=$ neutral detergent fiber, $\mathrm{CP}=$ crude protein, $\mathrm{EE}=$ ether extract, and $\mathrm{NFC}=$ nonfibrous carbohydrates. ${ }^{2}$ Extrusa of Marandu grass (DM basis) containing: $0.213 \%, 0.028 \%, 0.042 \%, 0.180 \%$ and $0.387 \%$ of palmitic acid (C16:0), stearic acid (C18:0), oleic acid (cis-9 C18:1), linoleic acid (cis-9, cis-12 C18:2) and $\alpha$-linolenic acid (cis-9, cis-12, cis-15 C18:3), respectively. 
There was no interaction effect of no effect was observed on the rumen $\mathrm{pH}$ or on the treatment*sampling time for any ruminal ruminal concentrations of ammonia $\mathrm{N}$, propionate parameter. A linear reduction $(\mathrm{P}<0.05)$ in the ruminal concentrations of acetate and total VFA in response to the inclusion of RS was observed, but and butyrate or on the molar proportions of acetate, propionate and butyrate (Table 6).

Table 5. Parameters of the dry matter (DM) and neutral detergent fiber (NDF) degradability of Marandu grass and kinetic parameters of the fluids in the rumen of Holstein $x$ Gyr cows receiving concentrates containing increasing amounts of roasted soybeans (RS).

\begin{tabular}{|c|c|c|c|c|c|c|c|}
\hline \multirow{2}{*}{ Parameter } & \multicolumn{4}{|c|}{ RS in the concentrate $(\mathrm{kg})$} & \multirow{2}{*}{$\begin{array}{l}\text { Standard error } \\
\text { of the mean }\end{array}$} & \multicolumn{2}{|r|}{ P-value } \\
\hline & 0.0 & 1.3 & 2.6 & 3.9 & & Linear & Quadratic \\
\hline \multicolumn{8}{|c|}{ Ruminal DM degradability } \\
\hline Potential degradability (\%) & 85.4 & 85.6 & 85.8 & 86.4 & 0.8575 & 0.3170 & 0.7274 \\
\hline Degradation rate $\left(\%\right.$ hour $\left.^{-1}\right)$ & 3.64 & 3.75 & 3.92 & 3.41 & 0.3029 & 0.7065 & 0.3234 \\
\hline Effective degradability (\%) & 50.3 & 50.8 & 51.4 & 49.8 & 1.0170 & 0.8133 & 0.3508 \\
\hline \multicolumn{8}{|c|}{ Ruminal NDF degradability } \\
\hline Potential degradability (\%) & 83.2 & 83.8 & 84.7 & 85.3 & 1.4012 & 0.1893 & 1.0000 \\
\hline Degradation rate $\left(\%\right.$ hour $\left.^{-1}\right)$ & 3.77 & 3.91 & 3.80 & 3.46 & 0.3610 & 0.4769 & 0.4568 \\
\hline Effective degradability (\%) & 40.2 & 40.8 & 40.7 & 39.4 & 1.3106 & 0.6710 & 0.4566 \\
\hline \multicolumn{8}{|c|}{ Kinetic parameters of the fluids in the rumen } \\
\hline Rate of passage $\left(\%\right.$ hour $\left.^{-1}\right)$ & 9.75 & 10.96 & 9.86 & 11.22 & 1.0958 & 0.1825 & 0.8858 \\
\hline Ruminal fluid volume (L) & 103.6 & 92.7 & 97.8 & 86.5 & 5.6867 & 0.0885 & 0.9297 \\
\hline
\end{tabular}

Table 6. Ruminal fermentation parameters of Holstein x Gyr cows grazing on Marandu grass supplemented with concentrates containing increasing amounts of roasted soybeans (RS).

\begin{tabular}{|c|c|c|c|c|c|c|c|}
\hline \multirow{2}{*}{ Item } & \multicolumn{4}{|c|}{ RS in the concentrate $(\mathrm{kg})$} & \multirow{2}{*}{$\begin{array}{c}\text { Standard error } \\
\text { of the mean }\end{array}$} & \multicolumn{2}{|c|}{$\mathrm{P}$-value } \\
\hline & 0.0 & 1.3 & 2.6 & 3.9 & & Linear & Quadratic \\
\hline $\mathrm{pH}$ & 5.93 & 5.96 & 5.95 & 5.98 & 0.1186 & 0.5917 & 0.9198 \\
\hline Ammonia $\mathrm{N}\left(\mathrm{mg} \mathrm{dL}^{-1}\right)$ & 13.83 & 14.07 & 13.41 & 13.52 & 2.4330 & 0.8787 & 0.9763 \\
\hline Acetate $(\mathrm{m} M)$ & 60.85 & 60.42 & 60.26 & 56.06 & 1.9065 & 0.0419 & 0.2200 \\
\hline Propionate $(\mathrm{m} M)$ & 15.30 & 14.64 & 14.63 & 13.79 & 0.6967 & 0.1063 & 0.8619 \\
\hline Butyrate $(\mathrm{m} M)$ & 8.60 & 8.14 & 8.20 & 7.49 & 0.5125 & 0.1710 & 0.7998 \\
\hline $\mathrm{VFA}^{1}(\mathrm{~m} M)$ & 84.75 & 83.20 & 83.10 & 77.33 & 2.6176 & 0.0438 & 0.3601 \\
\hline Acetate:propionate ratio & 3.99 & 4.20 & 4.13 & 4.13 & 0.1655 & 0.4940 & 0.3333 \\
\hline \multicolumn{8}{|l|}{ Molar proportions (\%) } \\
\hline Acetate & 71.86 & 72.74 & 72.51 & 72.54 & 1.2455 & 0.6379 & 0.6169 \\
\hline Propionate & 18.04 & 17.51 & 17.60 & 17.73 & 0.5817 & 0.6148 & 0.3655 \\
\hline Butyrate & 10.11 & 9.75 & 9.89 & 9.73 & 0.5826 & 0.5752 & 0.8089 \\
\hline
\end{tabular}

${ }^{1}$ VFA (volatile fatty acids $)=\Sigma$ ruminal concentrations of acetate + propionate + butyrate. 
The inclusion of RS promoted linear increases in milk fat $(\mathrm{P}=0.016)$ and total solid contents $(\mathrm{P}=0.039)$ and a linear reduction in the lactose content $(\mathrm{P}=0.008)$; however, no effect on the milk protein content and MUN content was observed. The fat-corrected milk (FCM) yield and fat, lactose and total solids yields were not influenced by the treatments, but a linear reduction $(\mathrm{P}=0.03)$ in protein yield in response to the inclusion of RS was observed (Table 7).

No effect of the treatments on the glucose and NEFA plasma contents (Table 8) was observed, and they were within the normal range for healthy cows ( $<0.4 \mathrm{mmol} \mathrm{L}^{-1}$ and $55-70 \mathrm{mg} \mathrm{dL}^{-1}$, respectively) (SANTOS, 2011).

Table 7. Milk yield and composition of Holstein x Gyr cows grazing on Marandu grass supplemented with concentrates containing increasing amounts of roasted soybeans (RS).

\begin{tabular}{|c|c|c|c|c|c|c|c|}
\hline \multirow{2}{*}{ Item } & \multicolumn{4}{|c|}{$\mathrm{RS}$ in the concentrate $(\mathrm{kg})$} & \multirow{2}{*}{$\begin{array}{l}\text { Standard error } \\
\text { of the mean }\end{array}$} & \multicolumn{2}{|c|}{ P-value } \\
\hline & 0.0 & 1.3 & 2.6 & 3.9 & & Linear & Quadratic \\
\hline \multicolumn{8}{|l|}{ Yield } \\
\hline Milk $\left(\mathrm{kg}\right.$ day $\left.^{-1}\right)$ & 19.8 & 20.4 & 19.9 & 17.9 & 1.6107 & 0.0852 & 0.0967 \\
\hline $\mathrm{FCM}^{1}\left(\mathrm{~kg} \mathrm{day}^{-1}\right)$ & 17.8 & 18.9 & 18.8 & 17.4 & 1.5820 & 0.6373 & 0.1008 \\
\hline Fat $\left(\mathrm{g} \mathrm{day}^{-1}\right)$ & 659.3 & 717.3 & 721.3 & 680.5 & 65.7275 & 0.6269 & 0.1462 \\
\hline Protein $\left(\mathrm{g} \mathrm{day}^{-1}\right)$ & 599.0 & 617.5 & 594.8 & 531.0 & 42.9156 & 0.0299 & 0.0613 \\
\hline Lactose $\left(\mathrm{g} \mathrm{day}^{-1}\right)$ & 853.3 & 876.0 & 852.8 & 767.8 & 76.3176 & 0.0600 & 0.0934 \\
\hline Total solids $\left(\mathrm{g} \mathrm{day}^{-1}\right)$ & 2.297 .3 & 2.402 .3 & 2.356 .8 & 2.150 .3 & 191.18 & 0.1984 & 0.0839 \\
\hline \multicolumn{8}{|l|}{ Composition (\%) } \\
\hline Fat & 3.33 & 3.52 & 3.63 & 3.78 & 0.1556 & 0.0164 & 0.8260 \\
\hline Protein & 3.03 & 3.04 & 3.00 & 3.01 & 0.1063 & 0.5419 & 0.9350 \\
\hline Lactose & 4.32 & 4.30 & 4.28 & 4.26 & 0.0915 & 0.0083 & 0.6569 \\
\hline Total solids & 11.62 & 11.79 & 11.85 & 11.99 & 0.1769 & 0.0397 & 0.8966 \\
\hline Milk urea nitrogen $\left(\mathrm{mg} \mathrm{dL}^{-1}\right)$ & 19.38 & 20.27 & 19.07 & 19.45 & 1.2211 & 0.7277 & 0.6903 \\
\hline
\end{tabular}

${ }^{1}$ Fat-corrected milk $\left(\right.$ NRC, 2001) $=0.4 *$ Milk Production $+15^{*}(\%$ Milk Fat $/ 100) *$ Milk Production.

Table 8. Plasma concentrations of glucose and nonesterified fatty acid (NEFA) of Holstein x Gyr cows grazing on Marandu grass supplemented with concentrates containing increasing amounts of roasted soybeans (RS).

\begin{tabular}{lccccccc}
\hline \multirow{2}{*}{ Metabolite } & \multicolumn{3}{c}{ RS in the concentrate $(\mathrm{kg})$} & Standard error & \multicolumn{2}{c}{ P-value } \\
\cline { 2 - 4 } & 0.0 & 1.3 & 2.6 & 3.9 & of the mean & Linear & Quadratic \\
\hline Glucose $\left(\mathrm{mg} \mathrm{dL}^{-1}\right)$ & 56.0 & 57.5 & 58.5 & 59.9 & 1.9886 & 0.0508 & 0.9669 \\
NEFA $\left(\mathrm{mmol} \mathrm{L}^{-1}\right)$ & 0.176 & 0.164 & 0.213 & 0.194 & 0.0327 & 0.3326 & 0.8602 \\
\hline
\end{tabular}

The inclusion of RS in the concentrate altered the contents of the majority of the FAs in the fat milk (Table 9). Among the main FAs, linear reductions $(\mathrm{P}<0.01)$ in the lauric, myristic and palmitic acid contents in the milk were observed, and linear increases $(\mathrm{P}<0.05)$ in the stearic, oleic, elaidic (trans-9 C18:1), linoleic and $\alpha$-linolenic acid contents in the milk were also observed.

Except for $\mathrm{C} 21: 0$ acid, the concentrations of all other odd- and branched-chain FAs (OBCFA) were linearly reduced $(\mathrm{P}<0.05)$ with the inclusion of 
$\mathrm{RS}$, which in turn did not alter the trans-10 C18:1, trans-11 C18:1, rumenic, trans-9, cis-11 CLA and trans-10, cis-12 CLA contents in the milk.

The inclusion of RS promoted linear reductions $(\mathrm{P}<0.05)$ in the secretion of lauric, myristic and palmitic acids and linear increases $(\mathrm{P}<0.05)$ in the secretion of stearic, oleic, linoleic and $\alpha$-linolenic acids but did not alter the secretion of trans-11
C18:1 and rumenic acids (Table 10).

Linear reductions in SCD activity for the pairs of FAs cis-9 C14:1/myristic ( $\mathrm{P}=0.056)$, cis-9 C16:1/ palmitic $(\mathrm{P}=0.016)$ and oleic/stearic $(\mathrm{P}=0.024)$ were observed in response to the inclusion of RS in the concentrate, but there was no effect on the pair of FAs rumenic/trans-11 C18:1 (Table 11).

Table 9. Milk fatty acid composition of Holstein x Gyr cows grazing on Marandu grass supplemented with concentrates containing increasing amounts of roasted soybeans (RS).

\begin{tabular}{|c|c|c|c|c|c|c|c|}
\hline \multirow{2}{*}{$\begin{array}{l}\text { Fatty acid - FA } \\
\left(\mathrm{g} 100 \mathrm{~g}^{-1} \mathrm{FA}\right)\end{array}$} & \multicolumn{4}{|c|}{ RS in the concentrate $(\mathrm{kg})$} & \multirow{2}{*}{$\mathrm{SEM}^{1}$} & \multicolumn{2}{|c|}{ P-value } \\
\hline & 0.0 & 1.3 & 2.6 & 3.9 & & Linear & Quadratic \\
\hline \multicolumn{8}{|l|}{ Linear even-chain saturated FAs } \\
\hline$\Sigma \mathrm{C} 4: 0+\mathrm{C} 6: 0+\mathrm{C} 8: 0+\mathrm{C} 10: 0$ & 8.35 & 8.22 & 7.40 & 6.75 & 0.5033 & 0.0004 & 0.1896 \\
\hline $\mathrm{C} 12: 0$ & 2.45 & 2.23 & 1.88 & 1.56 & 0.1625 & $<0.0001$ & 0.9427 \\
\hline $\mathrm{C} 14: 0$ & 10.38 & 8.85 & 8.03 & 6.71 & 0.6057 & $<0.0001$ & 0.6178 \\
\hline C16:0 & 28.25 & 22.56 & 22.10 & 21.14 & 1.4249 & 0.0052 & 0.1160 \\
\hline$\Sigma \mathrm{C} 12: 0+\mathrm{C} 14: 0+\mathrm{C} 16: 0$ & 41.18 & 33.64 & 32.01 & 29.40 & 1.9956 & 0.0012 & 0.1376 \\
\hline C18:0 & 12.04 & 14.67 & 16.09 & 17.29 & 0.9894 & 0.0019 & 0.3652 \\
\hline $\mathrm{C} 20: 0$ & 0.14 & 0.16 & 0.16 & 0.17 & 0.0101 & 0.0365 & 0.8829 \\
\hline $\mathrm{C} 22: 0$ & 0.065 & 0.070 & 0.073 & 0.076 & 0.0035 & 0.0638 & 0.8096 \\
\hline $\mathrm{C} 24: 0$ & 0.096 & 0.089 & 0.083 & 0.083 & 0.0077 & 0.2461 & 0.6859 \\
\hline$\Sigma \mathrm{C} 18: 0+\mathrm{C} 20: 0+\mathrm{C} 22: 0+\mathrm{C} 24: 0$ & 12.35 & 14.99 & 16.41 & 17.62 & 0.9994 & 0.0020 & 0.3714 \\
\hline \multicolumn{8}{|c|}{ Odd- and branched-chain FAs (OBCFA) } \\
\hline $\mathrm{C} 11: 0$ & 0.31 & 0.27 & 0.22 & 0.17 & 0.0330 & 0.0010 & 1.0000 \\
\hline $\mathrm{C} 13: 0$ & 0.058 & 0.056 & 0.049 & 0.042 & 0.0034 & 0.0121 & 0.4867 \\
\hline iso $\mathrm{C} 15: 0$ & 0.41 & 0.33 & 0.31 & 0.25 & 0.0257 & 0.0040 & 0.5690 \\
\hline anteiso $\mathrm{C} 15: 0$ & 0.71 & 0.60 & 0.54 & 0.49 & 0.0437 & 0.0096 & 0.5018 \\
\hline $\mathrm{C} 15: 0$ & 1.24 & 1.03 & 0.95 & 0.84 & 0.0463 & 0.0008 & 0.3564 \\
\hline $\mathrm{C} 17: 0$ & 0.57 & 0.50 & 0.47 & 0.44 & 0.0302 & 0.0097 & 0.4213 \\
\hline cis-9 C17:1 & 0.22 & 0.17 & 0.14 & 0.15 & 0.0142 & 0.0047 & 0.0591 \\
\hline $\mathrm{C} 21: 0$ & 0.030 & 0.028 & 0.028 & 0.030 & 0.0026 & 0.9149 & 0.3051 \\
\hline$\Sigma$ odd-linear-chain FAs & 2.43 & 2.04 & 1.84 & 1.66 & 0.0837 & 0.0006 & 0.2782 \\
\hline$\Sigma$ OBCFA & 3.55 & 2.97 & 2.69 & 2.40 & 0.1473 & 0.0013 & 0.3597 \\
\hline \multicolumn{8}{|l|}{ cis-monounsaturated FAs } \\
\hline cis-9 C14:1 & 1.00 & 0.73 & 0.60 & 0.51 & 0.1084 & 0.0033 & 0.2810 \\
\hline cis-9 C16:1 & 1.31 & 0.85 & 0.75 & 0.75 & 0.1108 & 0.0081 & 0.0851 \\
\hline cis-9 C18:1 & 20.52 & 23.62 & 23.30 & 25.05 & 1.1733 & 0.0189 & 0.4936 \\
\hline cis-11 C18:1 & 1.30 & 1.46 & 1.61 & 1.54 & 0.1050 & 0.0355 & 0.1735 \\
\hline cis-12 C18:1 & 0.35 & 0.45 & 0.48 & 0.50 & 0.0439 & 0.0370 & 0.4131 \\
\hline
\end{tabular}


continuation

\begin{tabular}{|c|c|c|c|c|c|c|c|}
\hline cis-13 C18:1 & 0.074 & 0.060 & 0.067 & 0.085 & 0.0098 & 0.3846 & 0.1389 \\
\hline cis-9 C20:1 & 0.035 & 0.037 & 0.042 & 0.048 & 0.0033 & 0.0048 & 0.3778 \\
\hline \multicolumn{8}{|l|}{ trans-C18:1 FAs } \\
\hline trans-4 & 0.021 & 0.028 & 0.039 & 0.041 & 0.0045 & 0.0024 & 0.5018 \\
\hline trans -5 & 0.017 & 0.030 & 0.031 & 0.029 & 0.0056 & 0.0379 & 0.0490 \\
\hline trans 6-8 & 0.19 & 0.20 & 0.24 & 0.25 & 0.0170 & 0.0145 & 1.0000 \\
\hline trans-9 & 0.27 & 0.33 & 0.31 & 0.34 & 0.0238 & 0.0496 & 0.4630 \\
\hline trans-10 & 0.22 & 0.25 & 0.29 & 0.30 & 0.0391 & 0.1010 & 0.7172 \\
\hline trans-11 & 2.64 & 2.69 & 2.99 & 2.95 & 0.2696 & 0.1682 & 0.7998 \\
\hline trans-12 & 0.32 & 0.38 & 0.45 & 0.44 & 0.0407 & 0.0299 & 0.3510 \\
\hline trans 13-14 & 0.30 & 0.41 & 0.36 & 0.36 & 0.0491 & 0.4788 & 0.2697 \\
\hline trans-16 & 0.32 & 0.39 & 0.35 & 0.39 & 0.0463 & 0.1721 & 0.5789 \\
\hline$\sum$ trans-C18:1 & 4.28 & 4.69 & 5.04 & 5.08 & 0.3595 & 0.0289 & 0.4308 \\
\hline \multicolumn{8}{|c|}{ Nonconjugated and conjugated (CLA) isomers of linoleic acid } \\
\hline cis-9, trans-12 C18:2 & 0.094 & 0.080 & 0.068 & 0.066 & 0.0071 & 0.0218 & 0.4274 \\
\hline cis-9, trans-11 CLA & 1.15 & 1.16 & 1.24 & 1.22 & 0.1229 & 0.5939 & 0.8893 \\
\hline trans -9 , cis-11 CLA & 0.041 & 0.036 & 0.050 & 0.038 & 0.0065 & 0.7742 & 0.5271 \\
\hline trans-10, cis-12 CLA & 0.019 & 0.014 & 0.018 & 0.017 & 0.0019 & 0.9689 & 0.2216 \\
\hline \multicolumn{8}{|l|}{ Long-chain polyunsaturated FAs } \\
\hline cis-9, cis-12 C18:2 ( $\omega-6)$ & 1.55 & 3.42 & 4.36 & 5.27 & 0.4583 & 0.0007 & 0.3080 \\
\hline cis-6, cis-9, cis-12 $\gamma-\mathrm{C} 18: 3(\omega-6)$ & 0.12 & 0.14 & 0.12 & 0.11 & 0.0069 & 0.2198 & 0.0520 \\
\hline cis-9, cis-12, cis-15 C18:3 ( $\omega-3)$ & 0.34 & 0.59 & 0.69 & 0.84 & 0.0565 & $<0.0001$ & 0.2010 \\
\hline cis-11, cis-14 C20:2 ( $\omega-6)$ & 0.023 & 0.032 & 0.032 & 0.033 & 0.0038 & 0.1116 & 0.3297 \\
\hline cis-8, cis-11, cis-14 C20:3 ( $\omega-6)$ & 0.071 & 0.094 & 0.086 & 0.077 & 0.0071 & 0.8357 & 0.0342 \\
\hline 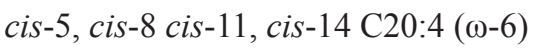 & 0.11 & 0.13 & 0.11 & 0.11 & 0.0104 & 0.3473 & 0.1572 \\
\hline
\end{tabular}

${ }^{1}$ Standard error of the mean.

Table 10. Secretion of fatty acids in the milk from Holstein x Gyr cows grazing on Marandu grass supplemented with concentrates containing increasing amounts of roasted soybeans (RS).

\begin{tabular}{|c|c|c|c|c|c|c|c|}
\hline \multirow{2}{*}{$\begin{array}{l}\text { Secretion of fatty acid* } \\
\left(\mathrm{g} \mathrm{cow}^{-1} \text { day }^{-1}\right)\end{array}$} & \multicolumn{4}{|c|}{ RS in the concentrate $(\mathrm{kg})$} & \multirow{2}{*}{$\begin{array}{l}\text { Standard error } \\
\text { of the mean }\end{array}$} & \multicolumn{2}{|c|}{ P-value } \\
\hline & 0.0 & 1.3 & 2.6 & 3.9 & & Linear & Quadratic \\
\hline $\mathrm{C} 12: 0$ & 15.7 & 15.1 & 12.8 & 10.1 & 2.0823 & 0.0002 & 0.0913 \\
\hline $\mathrm{C} 14: 0$ & 64.1 & 60.1 & 54.2 & 43.9 & 8.3542 & 0.0008 & 0.2289 \\
\hline $\mathrm{C} 16: 0$ & 174.1 & 151.4 & 148.3 & 136.4 & 19.2397 & 0.0445 & 0.6175 \\
\hline$\Sigma \mathrm{C} 12: 0+\mathrm{C} 14: 0+\mathrm{C} 16: 0$ & 253.8 & 226.6 & 215.2 & 190.3 & 29.1159 & 0.0123 & 0.9313 \\
\hline$\Sigma \mathrm{C} 4: 0+\mathrm{C} 6: 0+\mathrm{C} 8: 0+\mathrm{C} 10: 0+(1)$ & 305.3 & 282.2 & 265.2 & 234.8 & 36.3767 & 0.0125 & 0.8099 \\
\hline $\mathrm{C} 18: 0$ & 74.0 & 97.9 & 107.5 & 109.5 & 11.3458 & 0.0178 & 0.2200 \\
\hline$\Sigma \mathrm{C} 18: 0+\mathrm{C} 20: 0+\mathrm{C} 22: 0+\mathrm{C} 24: 0$ & 75.9 & 100.0 & 109.6 & 111.6 & 11.5730 & 0.0184 & 0.2223 \\
\hline cis-9 C18:1 & 124.9 & 156.6 & 156.3 & 153.9 & 10.7483 & 0.0288 & 0.0456 \\
\hline cis-9, cis-12 C18:2 & 9.3 & 22.7 & 29.3 & 31.6 & 2.8490 & 0.0008 & 0.0837 \\
\hline
\end{tabular}


continuation

\begin{tabular}{lccccccc} 
cis-9, cis-12, cis-15 C18:3 & 2.0 & 3.9 & 4.6 & 5.1 & 0.4090 & 0.0005 & 0.0745 \\
cis-9, trans-11 CLA & 6.9 & 7.6 & 8.2 & 7.7 & 0.7630 & 0.3529 & 0.4217 \\
trans-11 C18:1 & 16.0 & 17.6 & 19.7 & 19.0 & 2.0396 & 0.1379 & 0.4483 \\
\hline
\end{tabular}

*Calculated according to Mourthé et al. $(2015)$ : Secretion of fatty acid $=\left(\right.$ milk yield, $\mathrm{kg}$ day $\left.{ }^{-1}\right) *($ milk fat content, $\%) * 0.93 *($ milk fatty acid content, $\mathrm{g} 100 \mathrm{~g}^{-1}$ fatty acid), where 0.93 refers to the average content of fatty acids in milk fat.

Table 11. Indices of stearoyl-CoA desaturase (SCD) enzyme activity in Holstein x Gyr cows grazing on Marandu grass supplemented with concentrates containing increasing amounts of roasted soybeans (RS).

\begin{tabular}{|c|c|c|c|c|c|c|c|}
\hline \multirow{2}{*}{ Indice $^{1}$} & \multicolumn{4}{|c|}{$\mathrm{RS}$ in the concentrate $(\mathrm{kg})$} & \multirow{2}{*}{$\begin{array}{l}\text { Standard error } \\
\text { of the mean }\end{array}$} & \multicolumn{2}{|c|}{ P-value } \\
\hline & 0.0 & 1.3 & 2.6 & 3.9 & & Linear & Quadratic \\
\hline cis-9 C14:1/( cis-9 C14:1 + C14:0) & 0.087 & 0.076 & 0.069 & 0.069 & 0.0075 & 0.0563 & 0.3726 \\
\hline cis-9 C16:1/(cis-9 C16:1 + C16:0) & 0.044 & 0.036 & 0.033 & 0.034 & 0.0030 & 0.0156 & 0.1072 \\
\hline cis-9 C18:1/(cis-9 C18:1 + C18:0) & 0.631 & 0.617 & 0.592 & 0.591 & 0.0167 & 0.0238 & 0.5664 \\
\hline Rumenic/(rumenic + trans-11 C18:1) & 0.303 & 0.301 & 0.293 & 0.294 & 0.0146 & 0.4505 & 0.8807 \\
\hline
\end{tabular}

${ }^{1}$ Obtained as described by Kelsey et al. (2003): (product of SCD)/(product of SCD + substrate of SCD).

The inclusion of RS in the concentrate promoted linear reductions in AI $(\mathrm{P}=0.0008)$ and $\mathrm{IT}(\mathrm{P}=$ $0.0016)$ and a linear increase $(\mathrm{P}=0.002)$ in the $\mathrm{h} / \mathrm{H}$
FA ratio, but there was no effect $(\mathrm{P}>0.05)$ on the $\omega-6: \omega-3$ FA ratio (Table 12).

Table 12. Indices of the nutritional quality of milk fat from Holstein x Gyr cows grazing on Marandu grass supplemented with concentrates containing increasing amounts of roasted soybeans (RS).

\begin{tabular}{lcccccccc}
\hline \multirow{2}{*}{ Indice } & \multicolumn{3}{c}{$\mathrm{RS}$ in the concentrate $(\mathrm{kg})$} & \multirow{2}{*}{ SEM $^{1}$} & \multicolumn{3}{c}{ P-value } \\
\cline { 2 - 4 } & 0.0 & 1.3 & 2.6 & 3.9 & & & Linear & Quadratic \\
\hline Atherogenicity indice & 3.25 & 2.17 & 1.96 & 1.64 & 0.2645 & & 0.0008 & 0.0811 \\
Thrombogenicity indice & 4.17 & 2.97 & 2.85 & 2.58 & 0.2834 & 0.0016 & 0.0604 \\
Hypo/hypercolesterolemic fatty acids ratio & 0.52 & 0.73 & 0.75 & 0.90 & 0.0719 & 0.0020 & 0.6096 \\
$\omega-6 / \omega-3$ fatty acids ratio & 5.63 & 6.46 & 6.82 & 6.56 & 0.3434 & 0.0549 & 0.1160 \\
\hline
\end{tabular}

${ }^{1}$ Standard error of the mean.

\section{Discussion}

The similarities in the estimated DM and NDF intakes from pasture among the treatments (Table 4) are consistent with the absence of an effect of the inclusion of RS on the ruminal degradation parameters of pasture DM and NDF (Table 5). However, the estimated intakes of DM and NDF from the pasture and from the total diet (Table 4) were generally higher than those reported by
Mourthé et al. (2012), who evaluated the same experimental treatments. These differences in the magnitudes of the nutrient intake values cannot be attributed to the milk yields of the cows, which were, in general, similar in both studies. However, an incomplete fecal recovery of the chromic oxide associated with individual variation, as they are aspects inherent to the application of the external marker technique (LOPES, 2007), may eventually 
have caused the difference in the DM intake that was estimated in the two studies. However, this is just a hypothesis.

As the total DM intakes were similar among the treatments, there was also no effect of the inclusion of RS on the CP intake from the diet (Table 4).

However, the substitution of RS (source of EE) for energy sources rich in NFC (e.g., ground corn and citrus pulp) was responsible for the linear increase $(\mathrm{P}<0.0001)$ in the total EE intake, as well as the concomitant reduction $(\mathrm{P}=0.0143)$ in the NFC intake when RS was included in the concentrate (Table 4). The calculated EE dietary contents were $1.57 \%, 3.19 \%, 3.88 \%$ and $5.72 \% \mathrm{DM}$, respectively, for the diets that included $0,1.3,2.6$ and $3.9 \mathrm{~kg}$ RS in the concentrate, which were lower than the maximum limit of $6-7 \%$ recommended by the NRC (2001) to avoid a reduction in the DM intake, especially in the initial lactation phase of the cows.

As expected, the inclusion of $\mathrm{RS}$ in the diet promoted increases $(\mathrm{P}<0.0001)$ in the dietary intakes of palmitic, stearic, oleic, linoleic and $\alpha$-linolenic acids (Table 4), which are present in large concentrations in the concentrates and in the pasture (Tables 2 and 3). Regardless of the treatment and because linoleic acid is the major FA in all the concentrates (Table 3), it was the main FA consumed by the cows. In relation to the control treatment, the inclusion of RS promoted significant increases in linoleic acid intake of $213 \%, 320 \%$ and $562 \%$, respectively, in the diets with $1.3,2.6$ and $3.9 \mathrm{~kg} \mathrm{RS}$ in the concentrate (Table 4). As there was no effect $(\mathrm{P}>0.05)$ of the inclusion of RS in the concentrate on pasture DM intake, there was a similarity $(\mathrm{P}>0.05)$ among the treatments in oleic, linoleic and $\alpha$-linolenic acid intakes from the pasture (Table 4). However, due to the high content of $\alpha$-linolenic acid in pasture, the pasture contributed a significant fraction of the total $\alpha$-linolenic acid intake, and $\alpha$-linolenic acid was the third most consumed FA (Table 4). $\alpha$-Linolenic and linoleic acids are, together with oleic acid, the substrates for the formation of the trans-11 C18:1 via partial BH reactions in the rumen (SHINGFIELD et al., 2010).

The decrease in the amount of fermentable substrates in the rumen, resulting from the substitution of dietary ingredients for RS EE, may be partially responsible for the linear reductions $(\mathrm{P}=0.04)$ in the rumen acetate concentrations and, therefore, in total VFA, which were mainly observed in the treatment with the greatest inclusion of RS (Table 6). In relation to the control treatment, reductions of $7.9 \%$ and $8.8 \%$, respectively, were observed in the concentrations of acetate and total VFA in the rumen of the cows that received $3.9 \mathrm{~kg}$ of RS in the concentrate.

An effect $(\mathrm{P}=0.008)$ of the sampling time on the ruminal concentration of ammonia $\mathrm{N}$ was observed. Regardless of the treatment, and at any time of the day, it was below $10 \mathrm{mg} \mathrm{dL}^{-1}$ (data not shown). This value is considered adequate to meet the net requirement of the microbiota that ferments fibrous carbohydrates in the rumen and, preferably, uses ammonia $\mathrm{N}$ as a nitrogenous substrate for protein synthesis (VALADARES FILHO; PINA, 2011).

The mean values of ruminal $\mathrm{pH}$ ranged from 5.93 to 5.98 (Table 6) and were therefore below 6.0, which is considered the critical limit below which the degradation of cellulose is inhibited (VALADARES FILHO; PINA, 2011). However, there was no effect of the treatments on the ruminal degradability of NDF or DM pasture (Table 5). Despite the absence of an effect $(\mathrm{P}=0.35)$ of sampling time on the ruminal $\mathrm{pH}$, regardless of the treatment, the average $\mathrm{pH}$ was higher than 6.0 for only a few sampling times throughout the day, and the highest average value was 6.12 (data not shown). This $\mathrm{pH}$ may have moderately limited the activity of the fibrolytic microbiota and, consequently, caused there to be no differences among the treatments in the degradability of NDF and DM from the pasture (Table 5). However, the values of the pasture degradation parameters (Table 5) can be considered indicative of the good nutritional quality of the 
pasture consumed, which were, for example, all higher than those estimated by Lopes et al. (2010) for samples of Marandu grass at 56 days of forage growth.

Negative correlations $(\mathrm{P}<0.01 ; \mathrm{n}=128)$ between the $\mathrm{pH}$ and the ruminal concentrations of acetate $(\mathrm{r}$ $=-0.27)$ and total VFA $(r=-0.30)$ were observed. However, the linear reductions $(\mathrm{P}=0.04)$ observed for these metabolites in response to the inclusion of RS were not sufficient to promote a significant increase in rumen $\mathrm{pH}$ (Table 6). Cows under grazing that receive a moderate amount of concentrate, as in the present study, could be expected to have larger mean values of ruminal $\mathrm{pH}$, especially considering the high NDF intakes (Table 4). The absence of an effect of the treatments on the ruminal $\mathrm{pH}$ and on the NDF intake indicates that other factors besides the composition of the experimental concentrates, such as the times the concentrates were supplied and the feeding behavior of the cows under grazing, may have modulated the $\mathrm{pH}$ values. In this sense, in the summer, as discussed by Pires et al. (2001), cows interrupt grazing on pastures of tropical grasses between morning and afternoon milking, thus avoiding the hottest hours of the day. At this season of year, according to these authors, the two main grazing peaks are at sunrise and sunset, which are times of low ambient temperature. Thus, because the concentrates were supplied separately from the forage and at times far from those with higher grazing activity, it is possible that the large contribution of fermentable substrates from the concentrate was responsible, at least in part, for the lower ruminal $\mathrm{pH}$ values.

The absence of an effect of the inclusion of RS on the passage rate of the fluids in the rumen (Table 5) can be explained by the similarity in DM intake of the pasture, which was expressed in $\mathrm{kg} \mathrm{day}^{-1}$ and in percentage of live weight - \%LW (Table 4), and in the DM intake of the concentrates $(\% \mathrm{LW})$, which, according to Seo et al. (2006), are responsible for modulating the passage rate of the fluids in the rumen. For tropical grass hay-based diets, Bateman and Jenkins (1998) also did not observe an effect $(\mathrm{P}>0.05)$ of an inclusion of up to $8 \%$ soybean oil in the diet DM on the rumen fluids passage rate $(10.30$ to $10.74 \%$ hour $^{-1}$ ) and ruminal fluid volume (80.6 to $91.8 \mathrm{~L}$ ) in nonlactating cows.

Because the milk yield was similar among the treatments, there was no effect of the inclusion of RS on the FCM yield or on the yields of fat, lactose and total solids despite the linear increases observed in fat and total solids contents in the milk and the linear reduction in the lactose content (Table 7).

The synthesis of lactose is mainly modulated by plasma glucose synthesized via gluconeogenesis from the propionate produced in the rumen (SANTOS, 2011). The inclusion of RS did not alter the concentration of propionate in the rumen (Table 6) but promoted a linear increase $(\mathrm{P}=0.05)$ in the plasma glucose concentration (Table 8). According to $\mathrm{Wu}$ and Huber (1994), in diets supplemented with fat, the de novo synthesis of FA is reduced as a function of dietary FA incorporation. This reduction causes a reduction in the requirement for acetate and increases the availability of glucose for the synthesis of lactose. However, in the present study, despite the reduction in de novo FA synthesis (Tables 9 and 10) and the higher plasma glucose concentration (Table 8), there was no increase in lactose content in milk, which, in contrast, was linearly reduced in response to the inclusion of RS (Table 7). This result explains the absence of a correlation ( $\mathrm{P}=0.78)$ between plasma glucose and the milk lactose content, indicating that other factors may have modulated lactose synthesis in milk. One hypothesis is that the reduction in the lactose content of the milk could be associated with the reduction $(\mathrm{P}=0.01)$ in NFC intake (Table 4). However, there was also no correlation $(\mathrm{P}=0.81)$ between these variables.

When the control treatment was compared with the diet with $3.9 \mathrm{~kg}$ of RS in the concentrate, the increase in the milk fat content was $14 \%$. However, this increase was not reflected in the fat yield, which 
was similar between the treatments (Table 7). Thus, the absence of an effect of the inclusion of RS on the daily fat yield indicates that for the net balance of FA esterification of milk fat triglycerides, the reduction in the de novo-synthesized saturated FAs, which have a lower carbon chain length ( $\mathrm{C} 4: 0$ to C16:0), was apparently compensated for by the increase in dietary FAs (mainly from RS) in the rumen and/or synthesized in the mammary gland, such as, long chain saturated FAs C18:0 to C24:0, C18:1 FAs and polyunsaturated FAs (Table 9).

The linear increase $(\mathrm{P}<0.05)$ in the secretion of stearic, oleic, linoleic and $\alpha$-linolenic FAs in the milk and the linear reduction $(\mathrm{P}<0.05)$ in the FAs from the de novo synthesis (e.g., lauric, myristic, palmitic, $\Sigma$ C4:0 to C16:0 FAs) illustrate how the inclusion of RS affected the daily yield of these FAs (Table 10). When the control diet was compared with that with $3.9 \mathrm{~kg}$ of RS in the concentrate, there was an increase of $48 \%, 23 \%, 240 \%$ and $155 \%$ in the secretion of stearic, oleic, linoleic and $\alpha$-linolenic FAs, respectively. However, a reduction of $36 \%$, $32 \%$ and $22 \%$ in the secretion of lauric, myristic and palmitic acids was observed, respectively.

There was a positive correlation $(\mathrm{r}=0.70 ; \mathrm{P}=$ 0.002 ) between the milk fat content and the content of the long chain saturated FAs C18:0 to C24:0 in the milk. The content of de novo-synthesized FAs decreased by $27 \%$, while the contents of saturated long-chain FAs and polyunsaturated FAs increased by $43 \%$ and $193 \%$, respectively, in the milk of the cows that received $3.9 \mathrm{~kg}$ of $\mathrm{RS}$ in the concentrate compared with that in the milk from cows fed the control treatment (Table 9).

No effect of dietary $\mathrm{RS}$ on the milk protein content $(\mathrm{P}=0.54)$ was observed, but there was a linear reduction $(\mathrm{P}=0.03)$ in the yield of this component, which was mainly reduced when 3.9 $\mathrm{kg}$ of RS was included in the concentrate (Table 7). In diets supplemented with soybean meal versus $\mathrm{RS}$, the results for milk yield and milk protein content are inconsistent, as reported by $\mathrm{Wu}$ and
Huber (1994). In some studies, the inclusion of RS promoted a decrease in the milk protein content with no change in milk yield, while in others, there was a reduction in milk yield with no change in the milk protein content. The factors involved in modulating the effects promoted by the heat treatment of soybeans on the milk yield and composition of cows receiving RS may be associated with the lower intake of digestible nutrients and a lower availability of fermentable substrates in the rumen, reducing the bacterial $\mathrm{N}$ flux, as well as with the thermal processing used for toasting and the particle size of the supplied RS, etc. (TICE et al., 1993; WU; HUBER, 1994; DHIMAN et al., 1997; NRC, 2001). In a companion study, Mourthé et al. (2012) evaluated the same treatments in the present study and did not observe differences in milk yields corrected or not corrected for fat, or in the lactose and total solids yields, or in the milk protein content and MUN. These authors also reported an increase in the milk fat content in response to the inclusion of RS in the concentrate, but they did not observe an effect of the treatments on the contents of lactose and total solids in the milk or on the protein yield.

The inclusion of RS in the concentrate promoted a linear reduction $(\mathrm{P}<0.05)$ in milk FA contents from de novo synthesis in the mammary gland (Table 9), which is responsible for $100 \%$ of the secretion of C4:0, C6:0, C8:0, C10:0 and C12:0, approximately $95 \%$ of $\mathrm{C} 14: 0$, and $50 \%$ of $\mathrm{C} 16: 0$ in milk fat (KLIEM; SHINGFIELD, 2016). The reduction in the concentrations of these FAs in bovine milk fat in response to the inclusion of RS in the diet is well documented in the literature (DHIMAN et al., 1995; LIU et al., 2008; MOURTHÉ et al., 2015) and may be promoted by factors, such as i) limiting ruminal fermentation of fiber, resulting in lower concentrations of acetate and butyrate, and therefore reducing the plasma availability of precursors for de novo FA synthesis in the mammary gland (BERNARD et al., 2008; SHINGFIELD et al., 2010); ii) a high availability of long-chain FAs in the mammary gland and their 
selective and preferential incorporation into milk fat triglycerides, which is a detriment to the de novosynthesized FAs (SHINGFIELD et al., 2010); and iii) a reduction in the abundance of mRNAs and expression of lipogenic genes (e.g., ACAC, FASN, $S R E P B-1)$, which encode the transcription factors (e.g., SREPB-1) and key enzymes (e.g., acetylCoA carboxylase, FA synthetase) of de novo FA synthesis in response to the high concentration of long chain FAs in the mammary gland (JAYAN, 1998; BERNARD et al., 2008; KADEGOWDA et al., 2009; SHINGFIELD et al., 2010). Considering these factors and the present data, where a reduction in the rumen concentration of acetate was observed, the lower availability of acetyl-CoA in the mammary gland may have contributed to the reduction in $d e$ novo FAs and their secretion into the milk.

In addition, with diets that included $1.42 \mathrm{~kg}$ day $^{-1}$ of RS, Liu et al. (2008) observed an increase in the concentration of linoleic acid in the plasma of cows. Thus, it is possible that the increases in the stearic, oleic, linoleic and $\alpha$-linolenic acid contents in the milk are a consequence of the elevation in their plasma concentrations in those cows that received RS. A high availability of stearic, oleic, linoleic and $\alpha$-linolenic acids in plasma can inhibit enzymes related to de novo FA synthesis in the mammary gland. Kadegowda et al. (2009) observed that stearic acid promoted a reduction of $56 \%$ and $69 \%$, respectively, in the expression of acetyl-CoA carboxylase and FA synthetase enzymes. According to these authors, since there is no endogenous synthesis of stearic acid, which is primarily uptaken from the plasma, the mammary gland cells reduce de novo FA synthesis in favor of FA esterification reactions for milk fat triglycerides. Additionally, Dawson and Herbein (1996) and Jayan (1998) demonstrated that oleic, linoleic and $\alpha$-linolenic acids, as well as other long-chain unsaturated acids (e.g., rumenic and trans-11 C18:1 acids), promoted a reduction in de novo FA synthesis.

However, the fact that the preferential incorporation of long-chain FAs in milk fat is a detriment to de novo-synthesized FA can be exemplified by the high negative correlations observed between the contents of the $\mathrm{C} 4: 0-\mathrm{C} 16: 0$ FAs in the milk and the milk fat contents of stearic ( $\mathrm{r}$ $=-0.79 ; \mathrm{P}=0.0003)$, oleic, linoleic and $\alpha$-linolenic acids ( $\mathrm{r}=-0.86$ to $-0.88 ; \mathrm{P}<0.01$ ), for which the inclusion of RS promoted a linear increase in the milk (Table 9). Compared to the control treatment, a $44 \%, 22 \%, 240 \%$ and $147 \%$ increase, respectively, in the milk contents of stearic, oleic, linoleic and $\alpha$-linolenic acids were observed when $3.9 \mathrm{~kg}$ of RS was included in the concentrate (Table 9). The results show that an increase in the supply of the sources of these FAs in the diet increases their concentrations in the milk (DHIMAN et al., 1995; LIU et al., 2008; MOURTHÉ et al., 2015).

Studies have also reported increased a stearic acid content in milk fat from cows receiving diets supplemented with RS (DHIMAN et al., 1995; LIU et al., 2008; MOURTHÉ et al., 2015). This result may indicate that the $\mathrm{BH}$ of the monoand polyunsaturated FAs in the rumen was not impaired even under ruminal $\mathrm{pH}$ values below 6.0 during most of the day (data not shown). It should be pointed out that the main microorganisms responsible for the $\mathrm{BH}$ reactions of these FAs in the rumen are fibrolytic bacteria, which, in addition to being sensitive to ruminal $\mathrm{pH}<6.0$ (VALADARES FILHO; PINA, 2011), are also the most vulnerable to the bacteriostatic effects of polyunsaturated FAs (VLAEMINCK et al., 2006). However, despite the high intake of oleic, linoleic and $\alpha$-linolenic acids from the RS diets (Table 4), the protective properties of the oil caused by toasting reduced the availability of these FAs in the rumen, which, in their free form, are the substrates for the microbiota in the various ruminal $\mathrm{BH}$ pathways (SHINGFIELD et al., 2010). Thus, it is likely that the unsaturated FAs originating from the lipolysis of glyco- and phospholipids from the grass, especially their major FA ( $\alpha$-linolenic acid), were important substrates for the $\mathrm{BH}$ reactions that occurred in the rumen. The common final product of ruminal $\mathrm{BH}$ pathways is 
stearic acid, with the main intermediates being the trans-6-16 C18:1 and cis-10-15 C18:1 FAs, and conjugated isomers (e.g., rumenic acid, trans-9, cis-11 CLA and trans-10, cis-12 CLA) of linoleic acid (SHINGFIELD et al., 2010). Thus, due to the lower availability of the substrates for $\mathrm{BH}$ in the rumen, the inclusion of RS promoted a linear increase $(\mathrm{P}<0.05)$ in the milk content of only a few of the known intermediates of ruminal $\mathrm{BH}$ of oleic, linoleic and $\alpha$-linolenic acids, such as cis-11 C18:1, cis-12 C18:1, trans-4 to trans-8 C18:1, elaidic acid, trans-12 C18:1 and cis-9, trans-12 C18:2 (Table 9).

No effect of the treatments $(\mathrm{P}>0.05)$ on the milk contents of trans-11 C18:1 and trans-10 C18:1 was observed (Table 9). These FAs, together with elaidic acid, are among the major trans-C18:1 monounsaturated isomers formed by the ruminal $\mathrm{BH}$ pathway of linoleic acid (SHINGFIELD et al., 2010), which, regardless of the treatment, was quantitatively the most consumed FA (Table 4). Elaidic acid and trans-10 C18:1 have been associated with deleterious effects on cardiovascular health (ALMEIDA et al., 2014); therefore, increasing their milk contents is not desirable for human nutrition. However, the inclusion of RS promoted a linear increase $(P=0.05)$ in the content of elaidic acid in the milk (Table 9). In absolute terms, the levels of elaidic acid in the milk observed in the present study are near the lower limit of the range of values

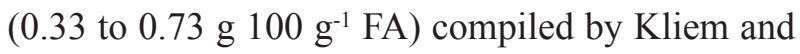
Shingfield (2016), who studied the inclusion of vegetable oils in diets supplied to cows. In addition, the observed contents of trans-10 C18:1 (Table 9) in the milks are well below the values reported by

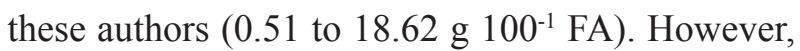
trans-11 C18:1 acid, which was the major isomer among the trans-C18:1 FAs, is the precursor for 70$95 \%$ of the synthesis of all rumenic acid secreted in bovine milk (KLIEM; SHINGFIELD, 2016). Therefore, diets that promote an increase in the supply of trans-11 C18:1 from the rumen to the mammary gland, in general, result in higher levels of rumenic acid in the milk. However, as there was no effect of the inclusion of RS on the content of trans-11 C18:1 in the milk, there was a similarity among treatments regarding the content of rumenic acid in the milk (Table 9). The contents of trans-11 C18:1 and rumenic acid in the milk were higher than those obtained by Mourthé et al. (2015), which

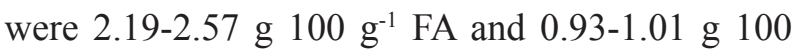
$\mathrm{g}^{-1}$ FA, respectively, when the same treatments were evaluated. These values can be considered high when compared to those of milk from cows receiving typical confinement diets based on conserved forages and concentrates, illustrating the potential of tropical grasses in the production of milk that is naturally enriched with rumenic acid and trans-11 C18:1 (LOPES et al., 2015).

A reduction in SCD activity was observed for the pairs of FAs cis-9 C14:1/myristic $(\mathrm{P}=0.0563)$, cis-9 C16:1/palmitic $(\mathrm{P}=0.01)$ and oleic/stearic $(\mathrm{P}$ $=0.02)$ in response to the inclusion of RS in the concentrate (Table 11), which contributed to the linear reductions $(\mathrm{P}<0.01)$ in the contents of cis-9 C14:1 and cis-9 C16:1 in the milk (Table 9). The linear reduction $(\mathrm{P}=0.02)$ in $\mathrm{SCD}$ activity for the pair of FAs oleic/stearic in response to the inclusion of RS in the concentrate (Table 10) highlights the importance of the contribution of oleic acid from $\mathrm{RS}$, which escapes ruminal $\mathrm{BH}$ and is uptaken from the plasma by the mammary gland for its secretion in milk. The esterification of the oleic acid at the $s n-3$ position of the triglyceride is an important mechanism of control for the melting point and the fluidity of milk fat (BERNARD et al., 2008).

Notably, the absence of an effect of SCD activity on the pair of FAs rumenic/trans-11 C18:1 may be related to the escape or reduction via $\mathrm{BH}$ of unsaturated FAs from RS in the rumen, causing a low availability of trans-11 C18:1 acid in the rumen, and subsequently in the plasma, to be used as a substrate for SCD in the mammary gland. According to Jayan (1998), an increase in the trans-11 C18:1 acid concentration in the bovine mammary epithelium was associated with higher SCD cellular activity. 
Leskinen et al. (2016) reported that the infusion of 10.4 to $31.2 \mathrm{~g} \mathrm{day}^{-1}$ of Co-EDTA per cow $(\approx$

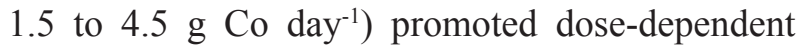
reductions in concentrations and secretion of FAs containing cis-9 double bond in milk. According to these authors, Co-EDTA partially inhibited or decreased the rate of desaturation of the SCD enzyme in the mammary gland of cows. In the present study, approximately $0.56 \mathrm{~g} \mathrm{day}^{-1}$ of Co was administered per cow, which is much lower than the value evaluated by Leskinen et al. (2016). In addition, the calculated values for the SCD activity indices (Table 11) were similar to those reported by Mourthé et al. (2015), who evaluated the same treatments as in the present study but did not administer Co-EDTA to the cows. In this study, the higher slope coefficient of the regression between the contents of rumenic acid and trans-11 C18:1 acid in the milk $\left(\hat{\mathrm{y}}=0.333733^{*} \mathrm{x}+0.24188 ; \mathrm{r}^{2}{ }_{\text {adj }}=\right.$ $0.56 ; \mathrm{P}=0.0005)$ than that presented by Mourthé et al. (2015) $\left(\hat{y}=0.322842 * x+0.1896 ; r^{2}=0.70\right.$; $\mathrm{P}<0.0001)$ indicates that the administration of CoEDTA did not reduce the SCD activity for the pair of FAs rumenic/trans-11 C18:1.

The inclusion of RS in the concentrate promoted a linear reduction $(\mathrm{P}<0.05)$ in the contents of most OBCFA in the milk (Table 9). These FAs originate from the digestion and absorption of lipids synthesized by the ruminal bacteria, as well as from the de novo synthesis of $\mathrm{C} 13: 0, \mathrm{C} 15: 0$ and $\mathrm{C} 17: 0$ FAs in the mammary gland, which use propionylCoA as a substrate (KLIEM; SHINGFIELD, 2016). The lower contents of OBCFA in the milk in response to the inclusion of RS can be considered indicative of the reduced activity and growth of bacterial communities as a consequence of the adaptive changes in the rumen environment of the cows (VLAEMINCK et al., 2006). The reduction in fermentable substrates in the rumen due to the inclusion of RS in the diet possibly contributed to limiting the development of the ruminal microbiota. This hypothesis is corroborated by the negative correlation $(\mathrm{r}=-0.86 ; \mathrm{P}<0.0001)$ between the content of OBCFA in the milk and EE intake. In addition, the positive correlation $(\mathrm{r}=0.69 ; \mathrm{P}<0.01)$ observed between the contents of C4:0-C16:0 FAs in the milk and OBCFA is another indication of the negative impact of the inclusion of RS on de novo synthesis of FAs in the mammary gland.

Except for linoleic acid, and cis-8, cis-11, cis-14 C20:3, there was no effect of the inclusion of RS in the concentrate on the contents of the other $\omega-6$ FAs in the milk (Table 9).

The inclusion of RS in the concentrate improved the nutritional quality of the milk fat since there were linear reductions in the $\mathrm{AI}(\mathrm{P}=0.0008)$ and IT $(\mathrm{P}=0.0016)$ and a linear increase $(\mathrm{P}=0.002)$ in the $\mathrm{h} / \mathrm{H}$ FA ratio (Table 12). This result may mainly be attributed to the decrease in the contents of lauric, myristic and palmitic hypercholesterolemic FAs in the milk (FAO, 2010) and the concomitant increase in the oleic acid content, and, specifically for the IT, may also be due to the increase in content of stearic acid in the milk (Table 9). The production of fat milk with a higher concentration of oleic acid, which is associated with a reduction in the cholesterol-LDL fraction, and lower concentrations of hypercholesterolemic FAs is desirable for human health because it may be associated with a reduction in the risk of cardiovascular diseases (FAO, 2010). There was no effect $(\mathrm{P}=0.0549)$ of the inclusion of RS on the $\omega-6: \omega-3$ FA ratio, which, according to FAO (2010), is not a useful index to measure the dietary recommendations aimed at reducing the risk of cardiovascular disease.

\section{Conclusions}

Supplementing Marandu grass with a concentrate containing up to $3.9 \mathrm{~kg}$ of roasted soybeans reduced the concentration of acetate in the rumen but did not alter the rumen degradability of the fiber from pasture, dry matter intake or milk yield. The inclusion of RS increased the milk fat content, which had a better nutritional quality from increases 
in the contents of oleic and $\alpha$-linolenic acids, which are beneficial to human health, and reductions in hypercholesterolemic fatty acid contents.

\section{Acknowledgements}

The authors acknowledge the Fundação de Amparo à Pesquisa de Minas Gerais (Fapemig), CAPES and Embrapa Dairy Cattle for scholarships and for financial support to carry out this study. The authors are grateful to the technician Hernani Guilherme Barbosa Filho who performed the fatty acid analysis at the Laboratory of Chromatography of Embrapa Dairy Cattle.

\section{References}

ALMEIDA, M. M.; LUQUETTI, S. C. D.; SABARENSE, C. M.; CORRÊA, J. O. A.; REIS, L. G.; CONCEIÇÃO, E. P. S.; LISBOA, P. C.; MOURA, E. G.; GAMEIRO, J.; GAMA, M. A. S.; LOPES, F. C. F.; GONZÁLEZ GARCIA, R. M. Butter naturally enriched in cis-9 trans-11 CLA prevents hyperinsulinemia and increases both serum HDL cholesterol and triacylglycerol levels in rats. Lipids in Health and Disease, London, v. 13, n. 200, p. 1-13, 2014.

ASSOCIATION OF OFFICIAL ANALYTICAL CHEMISTIS - AOAC. Official methods of analysis. AOAC Official Method 989.05. Fat in Milk (section 33.2.26). Washington: AOAC International, 2006.

ASSOCIATION OF OFFICIAL ANALYTICAL CHEMISTIS - AOAC. Official methods of analysis. $18^{\text {th }}$ ed. Washington: AOAC International, 2005.

BATEMAN, H. G.; JENKINS, T. C. Influence of soybean oil in high fiber diets fed to nonlactating cows on ruminal unsaturated fatty acids and nutrient digestibility. Journal of Dairy Science, Champaign, v. 81, n. 9, p. 2451-2458, 1998.

BERNARD, L.; LEROUX, C.; CHILLIARD, Y. Expression and nutritional regulation of lipogenic genes in the ruminant lactating mammary gland. In: BOSZE, Z. (Ed.). Bioactive components of milk. New York: Springer, 2008. p. 67-108.

CHRISTIE, W. W. A simple procedure for rapid transmethylation of glycerolipids and cholesterol esters. Journal of Lipid Research, Rockville, v. 23, n. 7, p. 10721075, 1982.
CRUZ-HERNANDEZ, C.; KRAMER, J. K. G.; KENNELLY, J. J.; GLIMM, D. R.; SORENSEN, B. M.; OKINE, E. K.; GOONEWARDENE, L. A.; WESELAKE, R. J. Evaluating the conjugated linoleic acid and trans 18:1 isomers in milk fat of dairy cows fed increasing amounts of sunflower oil and a constant level of fish oil. Journal of Dairy Science, Champaign, v. 90, n. 8, p. 3786-3801, 2007.

DAWSON, S. E.; HERBEIN, J. H. Influence of exogenous unsaturated fatty acids on de novo synthesis of saturated fatty acids in mouse and bovine mammary cell cultures. Virginia Journal of Science, Norfolk, v. 47, n. 2 , p. 138,1996 . Available at: <http://www.vacadsci. org/vjsArchives/V47/47-2/TitlePage.html> Accessed at: November 28, 2018.

DETMANN, E.; VALADARES FILHO, S. C.; BERCHIELLI, T. T.; CABRAL, L. S.; LADEIRA, M. M.; SOUZA, M. A.; QUEIROZ, A. C.; SALIBA, E. O. S.; PINA, D. P.; AZEVEDO, J. A. G. Métodos para análise de alimentos. Visconde do Rio Branco: Suprema, 2012. 214 p.

DHIMAN, T. R.; KOREVAAR, A. C.; SATTER L. D. Particle size of roasted soybeans and the effect on milk production of dairy cows. Journal of Dairy Science, Champaign, v. 80, n. 8, p. 1722-1727, 1997.

DHIMAN, T. R.; ZANTEN, K. V.; SATTER L. D. Effect of dietary fat source on fatty acid composition of cow's milk. Journal of the Science of Food and Agriculture, Oxford, v. 69, n. 1, p. 101-107, 1995.

FOOD AND AGRICULTURE ORGANIZATION OF THE UNITED NATIONS - FAO. Fats and fatty acids in human nutrition. Report of an expert consultation. Roma: FAO, 2010. 166 p.

HARTMAN, L.; LAGO, R. C. A. Rapid preparation of fatty acid methyl esters from lipids. Laboratory Practice, London, v. 22, n. 6, p. 475-477, 1973.

JAYAN, J. C. Activity and mRNA abundance of enzymes for fatty acid synthesis and desaturation in mammary cell cultures. 1998. Dissertation (Doctor of Philosophy) - Virginia Polytechnic Institute and State University, Blacksburg. Available in: $<$ https://vtechworks.lib.vt.edu/ handle/10919/40519> Accessed at: November 28, 2018.

KADEGOWDA, A. K. G.; BIONAZ, M.; PIPEROVA, L. S.; ERDMAN, R. A.; LOOR, J. J. Peroxisome proliferator-activated receptor- $\gamma$ activation and longchain fatty acids alter lipogenic gene networks in bovine mammary epithelial cells to various extents. Journal of Dairy Science, Champaign, v. 92, n. 9, p. 4276-4289, 2009. 
KELSEY, J. A.; CORL, B. A.; COLLIER, R. J.; BAUMAN, D. E. The effect of breed, parity, and stage of lactation on conjugated linoleic acid (CLA) in milk fat from dairy cows. Journal of Dairy Science, Champaign, v. 86, n. 8 , p. $2588-2597,2003$.

KLIEM, K. E.; SHINGFIELD, K. J. Manipulation of milk fatty acid composition in lactating cows: opportunities and challenges. European Journal of Lipid Science and Technology, Weinheim, v. 118, n. 11, p. 1661-1683, 2016.

KRAMER, J. K. G.; HERNANDEZ, M.; CRUZHERNANDEZ, C.; KRAFT, J.; DUGAN, M. E. R. Combining results of two GC separations partly achieves determination of all cis and trans 16:1, 18:1, 18:2 and 18:3 except CLA isomers of milk fat as demonstrated using Ag-ion SPE fractionation. Lipids, London, v. 43, n. 3, p. 259-273, 2008.

LESKINEN, H.; VIITALA, S.; MUTIKAINEN, M.; KAIRENIUS, P.; TAPIO, I.; TAPONEN, J.; BERNARD, L.; VILKKI, J.; SHINGFIELD, K. J. Ruminal infusions of Cobalt EDTA modify milk fatty acid composition via decreases in fatty acid desaturation and altered gene expression in the mammary gland of lactating cows. The Journal of Nutrition, Rockville, v. 146, n. 5, p. 976-985, 2016.

LIU, Z. L.; YANG, D. P.; CHEN, P.; LIN, S. B.; JIANG, X. Y.; ZHAO, W. S.; LI, J. M.; DONG, W. X. Effect of dietary sources of roasted oilseeds on blood parameters and milk fatty acid composition. Czech Journal of Animal Science, Praha, v. 53, n. 5, p. 219-226, 2008.

LOPES, F. C. F. Determinação do consumo de forrageiras tropicais por vacas em lactação, em condição de pastejo. Cadernos Técnicos de Veterinária e Zootecnia, Belo Horizonte, v. 52, p. 1-116, abr. 2007.

LOPES, F. C. F.; GAMA, M. A. S.; RIBEIRO, C. G. S.; MOURTHÉ, M. H. F.; BARROS, P. A. V.; SOUZA, S. M. Produção de leite com alto teor de CLA - experiência brasileira. In: PEREIRA, L. G. R.; NOBRE, M. M.; NEVES, A. L. A.; CAMPOS, M. M.; MENDONÇA, L. C.; GOMIDE, C. A. M.; SANTOS, G. G.; SIQUEIRA, K. B. Pesquisa, desenvolvimento e inovação para sustentabilidade da bovinocultura leiteira. Juiz de Fora: EMBRAPA Gado de Leite, 2011. p. 251-296.

LOPES, F. C. F.; PACIULLO, D. S. C.; MOTA, E. F.; PEREIRA, J. C.; AZAMBUJA, A. A.; MOTTA, A. C. S.; RODRIGUES, G. S.; DUQUE, A. C. A. Composição química e digestibilidade ruminal in situ da forragem de quatro espécies do gênero Brachiaria. Arquivo Brasileiro de Medicina Veterinária e Zootecnia, Belo Horizonte, v. 62, n. 4, p. 883-888, 2010.

LOPES, F. C. F.; SILVA, B. C. M.; ALMEIDA, M. M.;
GAMA, M. A. S. Lácteos naturalmente enriquecidos com ácidos graxos benéficos à saúde. In: MARTINS, P. C.; PICCININI, G. A.; KRUG, E. E. B.; MARTINS, C. E.; LOPES, F. C. F. Sustentabilidade ambiental, social e econômica da cadeia produtiva do leite: desafios e perspectivas. Brasília: EMBRAPA, 2015. p. 237309. Available at: <https://www.embrapa.br/en/gadode-leite/busca-de-publicacoes/-/publicacao/1021902/ sustentabilidade-ambiental-social-e-economica-dacadeia-produtiva-do-leite-desafios-e-perspectivas $>$ Accessed at: November 28, 2018.

MOURTHÉ, M. H. F.; REIS, R. B.; GAMA, M. A. S.; BARROS, P. A. V.; ANTONIASSI, R.; BIZZO, H. R.; LOPES, F. C. F. Perfil de ácidos graxos do leite de vacas Holandês x Gir em pastagem de capim-marandu suplementado com quantidades crescentes de grão de soja tostado. Arquivo Brasileiro de Medicina Veterinária e Zootecnia, Belo Horizonte, v. 67, n. 4, p. 1150-1158, 2015.

MOURTHÉ, M. H. F.; REIS, R. B.; LOPES, F. C. F.; GAMA, M. A. S.; SOUZA, R. C. Desempenho, composição do leite e metabólitos sanguíneos de vacas Holandês x Gir manejadas em pastagem de Brachiaria brizantha cv. Marandu e suplementadas com grão de soja tostado. Arquivo Brasileiro de Medicina Veterinária e Zootecnia, Belo Horizonte, v. 64, n. 5, p. 1223-1231, 2012.

NATIONAL RESEARCH COUNCIL - NRC. Nutrients requirements of dairy cattle. $7^{\text {th }} \mathrm{ed}$. Washington: National Academy Press, 2001. 381 p.

NOCEK, J. E. In situ and other methods to estimate ruminal protein and energy digestibility. a review. Journal of Dairy Science, Champaign, v. 71, n. 8, p. 2051-2069, 1988.

ØRSKOV, E. R.; McDONALD, I. The estimation of protein degradability in the rumen from incubation measurements weighted according to rate of passage. The Journal of Agricultural Science, Cambridge, v. 92, n. 2, p. 499-503, 1979.

PIRES, M. F. A.; VERNEQUE, R. S.; VILELA, D. Ambiente e comportamento animal na produção de leite. Informe Agropecuário, Belo Horizonte, v. 22, n. 211, p. $11-21,2001$.

SANTOS, J. E. P. Distúrbios metabólicos. In: BERCHIELI, T. T.; VAZ PIRES, A.; OLIVEIRA, S. G. (Ed.). Nutrição de ruminantes. 2. ed. Jaboticabal: FUNEP, 2011. p. 439-520.

SEO, S.; TEDESCHI, L. O.; LANZAS, C.; SCHWAB, C. G.; FOX, D. G. Development and evaluation of empirical equations to predict feed passage rate in cattle. Animal 
Feed Science and Technology, Amsterdan, v. 128, n. 1-2, p. 67-83, 2006.

SHINGFIELD, K. J.; BERNARD, L.; LEROUX, C.; CHILLIARD, Y. Role of trans fatty acids in the nutritional regulation of mammary lipogenesis in ruminants. Animal, Cambridge, v. 4, n. 7, p. 1140-1166, 2010.

TICE, E. M.; EASTRIDGE, L.; FIRKINS, J. L. Raw soybeans and roasted soybeans of different particle sizes. 1. Digestibility and utilization by lactating cows. Journal of Dairy Science, Champaign, v. 76, n. 1, p. 224-235, 1993.

TOMICH, T. R.; SAMPAIO, I. B. M. A new strategy for the determination of forage degradability with an in situ technique through the use of one fistulated ruminant. The Journal of Agricultural Science, Cambridge, v. 142, n. 5, p. 589-593, 2004.

TURPEINEN, A. M.; MUTANEN, M.; ARO, A.; SALMINEN, I.; BASU, S.; PALMQUIST, D. L.; GRIINARI, J. M. Bioconversion of vaccenic acid to conjugated linoleic acid in humans. The American Journal of Clinical Nutrition, Rockville, v. 76, n. 3, p. 504-510, 2002.

UDÉN, P.; COLUCCI, P. E.; VAN SOEST, P. J. Investigation of chromium, cerium and cobalt as markers in digesta. Rate of passage studies. Journal of Science and Food Agricultural, Oxford, v. 31, n. 7, p. 625-632, 1980.
VALADARES FILHO, S. C.; MACHADO, P. A. S.; CHIZZOTTI, M. L.; AMARAL, H. B.; MAGALHÃES, K. A.; ROCHA JÚNIOR, V. C.; CAPELLE, E. R. (Ed.). Tabelas brasileiras de composição de alimentos para bovinos. 3. ed. Viçosa, MG: UFV/DZO, 2010. 502 p.

VALADARES FILHO, S. C.; PINA, D. S. Fermentação ruminal. In: BERCHIELLI, T. T.; VAZ PIRES, A.; OLIVEIRA, S. G. (Ed.). Nutrição de ruminantes. 2. ed. Jaboticabal: FUNEP, 2011. p. 161-191.

VLAEMINCK, B.; FIEVEZ, V.; CABRITA, A. R. J.; FONSECA, A. J. M.; DEWHURST, R. J. Factors affecting odd- and branched-chain fatty acids in milk: a review. Animal Feed Science and Technology, Amsterdan, v. 131, n. 3/4, p. 389-417, 2006.

WOLFF, R. L.; BAYARD, C. C.; FABIEN, R. J. Evaluation of sequential methods for the determination of butterfat fatty acid composition with emphasis on trans-18:1 acids. Application to the study of seasonal variations in French butters. Journal of the American Oil Chemists' Society, Urbana, v. 72, n. 12, p. 1471-1483, 1995.

WU, Z.; HUBER, J. T. Relationship between dietary fat supplementation and milk protein concentration in lactating cows: a review. Livestock Production Science, Amsterdan, v. 39, n. 2, p. 141-155, 1994.

YANG, B.; CHEN, H.; STANTON, C.; ROSS, R. P.; ZHANG, H.; CHEN, Y. Q.; CHEN, W. Review of the roles of conjugated linoleic acid in health and disease. Journal of Functional Foods, Amsterdan, v. 15, p. 314325, may 2015. 